\title{
1 A kinetic study for NO catalytic reduction on silica sub-micron diameter tubes \\ 2 with platinum nanoparticles
}

3 Juana M. Rosas, Ramiro Ruiz-Rosas, José Rodríguez-Mirasol*, Tomás Cordero

4 Universidad de Málaga, Andalucía Tech, Dpto. de Ingeniería Química, 29071 Málaga,

\section{$7 \quad$ ABSTRACT}

8 The selective catalytic reduction (SCR) of $\mathrm{NOx}$ with $\mathrm{C}_{3} \mathrm{H}_{6}$ in the presence of $\mathrm{O}_{2}$ on

9 silica sub-microtubes with platinum nanoparticles was studied in order to establish a

10 possible reaction mechanism at different experimental conditions. This catalyst showed

11 a high NO conversion with very high selectivity to $\mathrm{N}_{2}$ at mild conditions in the presence

12 of excess oxygen when using $\mathrm{C}_{3} \mathrm{H}_{6}$ as reducing agent.

13 The influence of both $\mathrm{NO}$ and $\mathrm{C}_{3} \mathrm{H}_{6}$ concentrations on their conversions-was analyzed at

14 different space times. The obtained results suggest that the three reactants $\left(\mathrm{C}_{3} \mathrm{H}_{6}, \mathrm{NO}\right.$,

15 and $\mathrm{O}_{2}$ ) are adsorbed on Pt sites. The kinetic model proposed considers that both

16 dissociative adsorption of $\mathrm{NO}$ and activation of the hydrocarbon can take place

17 simultaneously. Nevertheless, the value of the parameters obtained by the resolution of

the model equations indicates that the first one presents a major relevance. These results are in concordance with the high selectivity to $\mathrm{N}_{2}$ observed, because the preponderance presence of dissociated $\mathrm{NO}$ avoids the formation of $\mathrm{N}_{2} \mathrm{O}$ by the reaction of molecular

$21 \mathrm{NO}$ with $\mathrm{N}$ dissociated from $\mathrm{NO}$. Furthermore, both $\mathrm{NO}$ reduction and $\mathrm{C}_{3} \mathrm{H}_{6}$ oxidation

22 conversions are represented reasonably well by the model presented.

23 Keywords: NOx; SCR; platinum; nanoparticles; silica nanotubes; coaxial electrospinning;

24 reaction mechanism 


\section{INTRODUCTION}

26

27

$\mathrm{NO}_{\mathrm{x}}\left(\mathrm{NO} \& \mathrm{NO}_{2}\right)$ exhausted from vehicles and stationary combustion engines is one of the important causes of photochemical smog, acid rain, and ozone depletion, which possess serious challenges to human health and environmental protection [1]. Selective catalytic reduction (SCR) technology with hydrocarbons is believed to be one of the most promising options for DeNOx [2]. However, SCR usually requires rather high reaction temperature (over $300{ }^{\circ} \mathrm{C}$ ) when hydrocarbons $(\mathrm{HCs})$ or $\mathrm{CO}$ are used as reducing agents [3]. If SCR of NOx with $\mathrm{HC}$ occurs at low temperature over catalyst with high DeNOx activity, the technology could compete with $\mathrm{NH}_{3}-\mathrm{SCR}$ and be more practical for the removal of NOx at stationary or mobile sources [1].

Catalysts based on platinum have been pointed out as potential candidates for this process. Obuchi et al. (1993) demonstrated that at lower temperatures (typically below $300{ }^{\circ} \mathrm{C}$ ) these metals could catalyze NOx reduction by the hydrocarbons found in the exhaust (e.g. propane and propylene) under lean-burn conditions [4]. It is found that $\mathrm{Pt}$ has the highest NOx reduction activity under lean conditions among the platinum group metals $[5,6]$. However, this high activity is accompanied by low $\mathrm{N}_{2}$ selectivity, i.e. large quantities of $\mathrm{N}_{2} \mathrm{O}$ are formed over Pt under lean conditions [5]. And $\mathrm{N}_{2} \mathrm{O}$ is an important greenhouse gas and air pollutant, having much more impact per unit mass (global warming potential) than carbon dioxide according to the Environmental Protection Agency (EPA) [7].

Regarding the reaction mechanism, the technical literature proposes two main reaction pathways for low temperature selective catalytic reduction of $\mathrm{NO}$ on Pt catalysts. The first one involves production of molecular nitrogen through NO dissociative adsorption via a redox mechanism $[8,9]$. According to this scheme, $\mathrm{NO}$ is adsorbed on the $\mathrm{Pt}$ 
surface and dissociates to yield adsorbed nitrogen and oxygen atoms, which desorb in the form of molecular $\mathrm{N}_{2}$ and/or $\mathrm{N}_{2} \mathrm{O}$, due to the reaction between two dissociated nitrogens and by one dissociated nitrogen and molecular NO, respectively. The role of the reductant is to react with adsorbed oxygen atoms and regenerate the active sites. The other mechanism proposes that the activation of the hydrocarbon plays the key role in the lean-DeNO $\mathrm{S}_{\mathrm{x}}$ reaction. In this sense, the activated hydrocarbon can react with adsorbed $\mathrm{NO}$ or $\mathrm{NO}_{2}$ [10-12] to form organo-nitro species that later decomposes as $\mathrm{N}_{2}$ or $\mathrm{N}_{2} \mathrm{O}$. It has been also suggested that the adsorbed hydrocarbon can react with $\mathrm{NO}$ to form $\mathrm{C}_{\mathrm{x}} \mathrm{H}_{\mathrm{y}} \mathrm{O}_{\mathrm{z}} \mathrm{N}_{\mathrm{w}}$ species [13,14], which would be later removed from the surface by reaction with oxygen, thus regenerating the active sites.

This research group has reported results on the preparation and characterization of silica sub-microtubes loaded with platinum nanoparticles, which showed a high activity and total selectivity to $\mathrm{N}_{2}$ at mild conditions, in the presence of excess oxygen, when using $\mathrm{C}_{3} \mathrm{H}_{6}$ as reducing agent [15]. Therefore, the aim of this work is to deepen into the behavior of this catalyst on this process, analyzing its performance under different experimental conditions to establish a possible mechanism for $\mathrm{NO}$ reduction by $\mathrm{C}_{3} \mathrm{H}_{6}$ in the presence of $\mathrm{O}_{2}$. The experimental results have been correlated with a kinetic model that represents adequately these experimental data.

\section{MATERIALS AND METHODS}

\subsection{Catalyst preparation}

The silica sol was prepared from tetraethyl orthosilicate (TEOS), ethanol, distilled water, and $\mathrm{HCl}$. The sol composition in molar ratio was 1:2:2:0.025

(TEOS:ethanol:water:HCl). Platinum (II) acetylacetonate was added to the solution in a 
72 molar ratio to TEOS of 0.006 . A more detailed explanation of the sol gel preparation

73 can be found elsewhere [15].

74 Silica sub-microtubes were generated by using the coaxial electrospinning method

75 reported in the literature [16] in a co-axial configuration, with the sol gel, which plays

76 the role of carrier, coming through the external capillary tip and synthetic oil flowing

77 through the inner one. The flow rates through the needles were around $0.6 / 1.5 \mathrm{~mL} \cdot \mathrm{h}^{-1}$

78 for sol gel/synthetic oil, respectively. To apply the high voltage between the spinneret

79 and the collector, two high voltage power supplies are used: one positively polarized

80 connected to the needle and the other one negatively polarized attached to a collector.

81 The tip-to-collector distance was $20-25 \mathrm{~cm}$, and the electrical potential difference was

$8210 \mathrm{kV}$ (the collector was at $-5 \mathrm{kV}$ and the tips at $+5 \mathrm{kV}$ ).

83 The electrospun tubes with platinum, denoted as SiT-Pt, were easily collected as a

84 flexible non-woven mat, and were calcined at $500^{\circ} \mathrm{C}$ for 2 hours in order to stabilize 85 them.

\section{2.2. Catalyst characterization}

87 A deep characterization was already performed and reported [15]. In this work, the

88 surface chemistry of the samples before and after the reaction at different experimental

89 conditions was studied by X-ray photoelectron spectroscopy (XPS) analysis, using a

$90 \quad 5700 \mathrm{C}$ model Physical Electronics apparatus with $\mathrm{MgK} \alpha$ radiation (1253.6 eV). For the

91 analysis of the XPS peaks, the $\mathrm{C} 1 \mathrm{~s}$ peak position was set at $284.5 \mathrm{eV}$ and used as

92 reference to locate the other peaks. The fitting of the XPS peaks was done by least

93 squares using Gaussian-Lorentzian peak shapes.

94 The surface and inner morphology of the tubes was studied by scanning electron

95 microscopy (SEM) using a JSM 840 JEOL microscope working at $25 \mathrm{KV}$ voltage and 
by transmission electron microscopy (TEM) in a Philips CM200 microscope at an accelerating voltage of $200 \mathrm{kV}$ and in a high angle annular dark field (HAADF)FEI Titan G2.

\subsection{NO Selective Catalytic Reduction (SCR) experiments}

The NO reduction experiments were performed in a quartz fixed bed microreactor ( 4 $\mathrm{mm}$ i.d.) at atmospheric pressure. Experiments were carried out with $80 \mathrm{mg}$ of catalyst. The total flow rate was varied from 100 to $250 \mathrm{~cm}^{3} \mathrm{STP} / \mathrm{min}$ for different concentrations of $\mathrm{NO}$ ranging from 200 to $800 \mathrm{ppm}$ and $\mathrm{C}_{3} \mathrm{H}_{6}$ from 200 to $1500 \mathrm{ppm}$. The concentrations of other inlet gases were $3 \%$ for $\mathrm{O}_{2}$ and $200 \mathrm{ppm}$ for $\mathrm{N}_{2} \mathrm{O}$. A chemiluminiscent analyzer (EcoPhysics, CLD 700 AL model) was used to measure the outlet gas concentrations of $\mathrm{NO}$ and $\mathrm{NO}_{2}$. The $\mathrm{CO}$ and $\mathrm{CO}_{2}$ outlet concentrations were analyzed by means of a non-dispersive infra-red analyser (Ultramat 22, Siemens model). $\mathrm{C}_{3} \mathrm{H}_{6}, \mathrm{H}_{2} \mathrm{O}, \mathrm{N}_{2}, \mathrm{~N}_{2} \mathrm{O}$ and $\mathrm{O}_{2}$ concentrations were measured by a mass spectrometer analyzer (Balzers MsCube).

\subsection{Kinetic analyses}

The mathematical equations to describe the NO reduction rates in the presence of propylene (as reducing agent) and oxygen are obtained by establishing the kinetic rate equation and then solving the molar balance to the fixed-bed reactor. The following assumptions were taken into account: homogeneous distribution of active sites on the catalyst surface; axial dispersion was discarded by adequate fixed bed length and reactor geometry $(\mathrm{L} / \mathrm{D}>20)$; the reactor operated at steady-state conditions; diffusional constraints and transport limitations were negligible; and changes in temperature and pressure within the reactor were neglected. 
119 Plug flow integral reactor can be used for the interpretation of the experimental data. To

120 this purpose the reactor mass balance equations (1) and (2) were numerically and 121 simultaneously integrated to calculate the exit conversion of the NO reduction and $\mathrm{C}_{3} \mathrm{H}_{6}$ 122 oxidation reactions,

123

$\frac{d X_{N O}}{d\left(\frac{W}{F_{N O}}\right)}=r_{N O} \quad \therefore \int_{0}^{X_{N O}} d X_{N O}=\int_{0}^{W / F_{N O}} r_{N O} \cdot d\left(\frac{W}{F_{N O}}\right)$

124

$\frac{d X_{C 3 H 6}}{d\left(\frac{W}{F_{C 3 H 6}}\right)}=r_{C 3 H 6} \quad \therefore \int_{0}^{X_{C 3 H 6}} d X_{C 3 H 6}=\int_{0}^{W / F_{C 3 H 6}} r_{C 3 H 6} \cdot d\left(\frac{W}{F_{C 3 H 6}}\right)$

125 where $r_{\mathrm{NO}}$ and $r_{\mathrm{C} 3 \mathrm{H}}$ represent the reaction rates of nitric oxide reduction and propylene 126 oxidation $\left(\mathrm{mol} \cdot \mathrm{s}^{-1} \cdot \mathrm{g}^{-1}\right)$, respectively; $X_{N O}$ and $X_{C 3 H 6}$ are the total conversions of NO and 127 propylene, and $\left(W / F_{N O}\right)$ and $\left(W / F_{C 3 H 6}\right)$ are the nitric oxide and propylene space times, 128 respectively. The reaction progress towards each product formation can be calculated in 129 the same way if required.

130 The dependence with the temperature of the kinetic and thermodynamic parameters, 131 involved in the proposed mechanisms, was considered to follow the Ahrrenius (3) or the 132 Van't Hoff law (4), respectively,

$$
k_{i}=k_{o i} \exp \left(\frac{-E_{a i}}{R T}\right)
$$

134

$$
K_{i}=K_{o i} \exp \left(\frac{-\Delta H_{i}}{R T}\right)
$$

135 where $k_{o i}$ and $K_{o i}$ are the pre-exponential factors, $E_{a i}$ the activation energy of the reaction 136 (i) and $\Delta H_{i}$ the enthalpy of the equilibrium (i). The optimization of the Arrhenius and 
137 Van't Hoff parameters involved in these equations were performed by minimizing the 138 objective function:

$$
O . F .=\sum_{i}\left(X_{i}^{\exp }-X_{i}^{c a l}\right)^{2}
$$

where $X_{i}^{\exp }$ represents the value of the experimental conversions of the reactives involved

141 in the model proposed and $X_{i}^{c a l}$ the ones calculated by solving the differential rate 142 equations system by a modified Runge-Kutta method with Matlab 2013b software. The 143 minimization of the equation (5) was based on the Levenberg-Marquart algorithm. The 144 optimized kinetic parameters are used to simulate the conversion profiles at different temperatures, initial gas pressures, $\mathrm{NO}$ and propylene space times and inlet compositions.

\section{RESULTS AND DISCUSSION}

Figures 1a and $\mathrm{b}$ present SEM and TEM micrographs of the catalyst, respectively. As

can be seen, the catalyst used consists of submicrometric tubes, very uniform in size and shape. The submicrometric tubes present total BET surface area of $144 \mathrm{~m}^{2} / \mathrm{g}$ and around $1 \%(\mathrm{wt})$ of Pt. Figure $1 \mathrm{c}$ and d despite high-angle annular dark field scanning transmission electron microscopy (HAADF-STEM) image of the wall of the submicrotube. The micrographs show the presence of well-dispersed platinum nanoparticles of around $2 \mathrm{~nm}$. Furthermore, the selected electron diffraction pattern of the Pt nanoparticles suggests the mainly presence of metallic platinum.
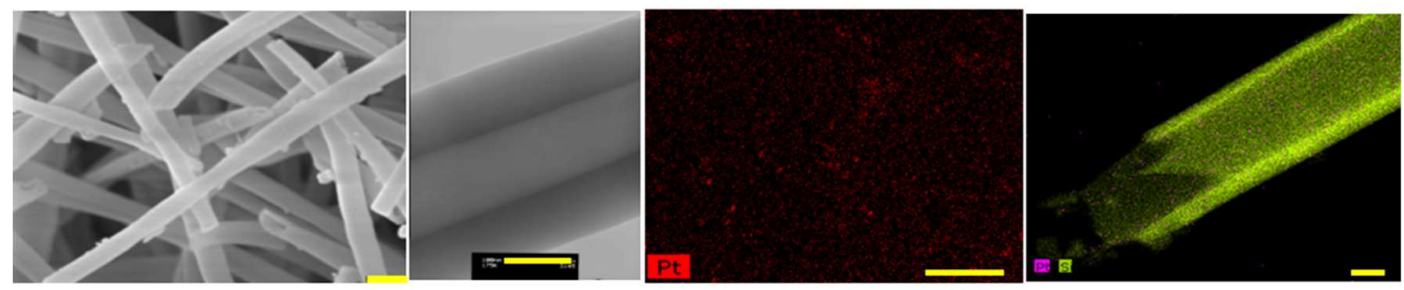
156 Figure 1. a) SEM image, bar length $(1 \mu \mathrm{m})$; b) TEM micrograph of the catalyst, bar 157 length (100 nm); c) HAADF-STEM of the catalyst surface (Pt:red particles), bar length 158 (50 nm); d) HAADF-STEM of submicrotubes (Pt:pink particles; Si: green particles), 159 bar length $(50 \mathrm{~nm})$.

160 Figure 2 shows the evolution of outlet gas concentration as a function of the reaction 161 time for an experiment where the inlet gases were added sequentially to the catalyst 162 previously described. Initially, only NO diluted in $\mathrm{He}\left(200 \mathrm{ppm}, \mathrm{W} / \mathrm{F}_{\mathrm{NO}}=2.88\right.$ $163 \mathrm{~g} \cdot \mathrm{s} / \mu \mathrm{mol})$ was introduced in the reactor at $210^{\circ} \mathrm{C}$. After around $60 \mathrm{~min}, \mathrm{O}_{2}(3 \% \mathrm{vol})$ 164 was added to the inlet stream and, finally, at around 120 min of reaction time, $\mathrm{C}_{3} \mathrm{H}_{6}$ 165 (1500 ppm) was also introduced. In the first step only a low adsorption of NO was 166 observed and no reaction products were detected. With the addition of oxygen to the 167 inlet stream, about $50 \%$ of $\mathrm{NO}$ is oxidized to $\mathrm{NO}_{2}$, due to the well-known high activity 168 of metallic platinum as oxidation catalyst. With the addition of $\mathrm{C}_{3} \mathrm{H}_{6}$, the presence of $169 \mathrm{NO}_{2}$ in the outlet gases is practically negligible. In this sense, some authors suggested that propylene is strongly adsorbed on the catalyst surface, decreasing the surface

171 coverage of oxygen. This fact reduces the probability of the NO and $\mathrm{O}$ adsorption at 172 adjacent vacant sites, and so, the presence of propylene may be considered to inhibit the 173 surface oxidation of $\mathrm{NO}$ to $\mathrm{NO}_{2}$ [3,17-19]. In this step, the conversion of $\mathrm{NO}$ is slightly 174 improved; however, the selectivity is total to $\mathrm{N}_{2}$. No formation of $\mathrm{N}_{2} \mathrm{O}$ was detected, at 175 least, within our detection limits, suggesting that NO was quickly dissociated, and no 176 molecular $\mathrm{NO}$ adsorption was taken place $[17,18,20]$, avoiding the formation of $\mathrm{N}_{2} \mathrm{O}$

177 that is one of the main drawbacks reported in the literature for platinum catalysts $178[11,21,22]$. Regarding propylene, there is not an equimolar ratio between NO and 179 propylene converted, because the reductant is also able to be directly oxidized by 180 oxygen at this reaction temperature, producing equals amounts of $\mathrm{CO}_{2}$ and $\mathrm{H}_{2} \mathrm{O}$. 


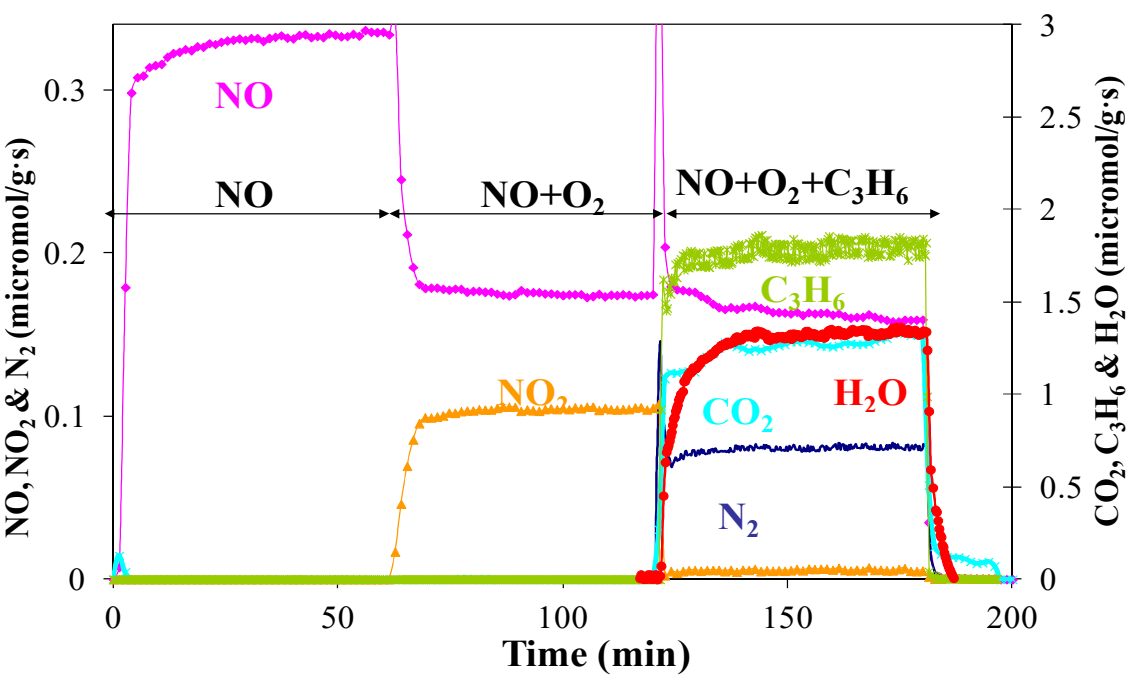

Figure 2. Evolution of outlet gas concentration as a function of reaction time, with 200 ppm $_{\mathrm{V}} \mathrm{NO}, 3 \% \mathrm{v} \mathrm{O}_{2}$ and $1500 \mathrm{ppm}_{\mathrm{v}} \mathrm{C}_{3} \mathrm{H}_{6}$, at $210^{\circ} \mathrm{C}, \mathrm{W} / \mathrm{F}_{\mathrm{NO}}=2.88 \mathrm{~g} \cdot \mathrm{s} / \mu \mathrm{mol}$.

The stability of the catalyst under different experimental conditions is another important aspect for catalytic applications. The good behavior observed for the catalyst under atmospheres containing $\mathrm{SO}_{2}$ was already reported in a previous work [15]. Now, the activity of the catalyst was evaluated at different reaction temperatures and inlet concentrations, and no signals of deactivation were observed. As an example, Figure 3 represents the NO conversion as a function of the time on stream with 200 ppmv NO, 1500 ppmv $\mathrm{C}_{3} \mathrm{H}_{6}$ and $3 \% \mathrm{O}_{2}$, at $200{ }^{\circ} \mathrm{C}, \mathrm{W} / \mathrm{F}_{\mathrm{NO}}=2.88 \mathrm{~g} \cdot \mathrm{s} / \mu \mathrm{mol}$. As can be seen, the catalyst showed the same activity along the experiment, with the same selectivity toward $\mathrm{N}_{2}$ and the corresponding characterization analyses of the catalyst after 8 hours of reaction indicated no significant changes on its properties. 


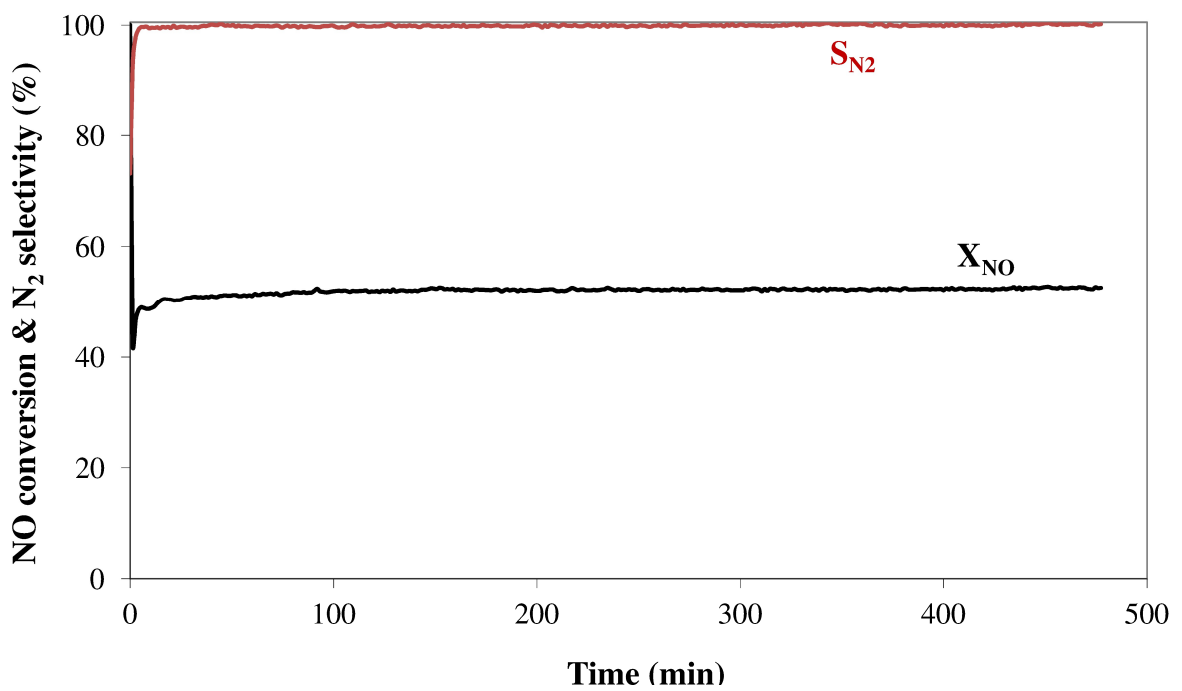

196 Figure 3. NO conversion and $\mathrm{N}_{2}$ selectivity as a function of time on stream with

197200 ppmv NO, 1500ppmv $\mathrm{C}_{3} \mathrm{H}_{6}$ and $3 \% \mathrm{O}_{2}$, at $200{ }^{\circ} \mathrm{C}, \mathrm{W} / \mathrm{F}_{\mathrm{NO}}=2.88 \mathrm{~g} \cdot \mathrm{s} / \mu \mathrm{mol}$.

\subsection{Influence of NO concentration on its reduction}

200

201

202

203

204

205

206

207

208

209

210

211
The effect of NO concentration on the SCR with 1500 ppmv $\mathrm{C}_{3} \mathrm{H}_{6}$ and $3 \% \mathrm{O}_{2}$ was evaluated at different temperatures and at fixed $\mathrm{W} / \mathrm{F}_{\mathrm{NO}}=1.92 \mathrm{~g} \cdot \mathrm{s} / \mu \mathrm{mol}$. Figure $4 . \mathrm{a}-\mathrm{b}$ shows the corresponding $\mathrm{NO}$ and $\mathrm{C}_{3} \mathrm{H}_{6}$ conversions as a function of $\mathrm{NO}$ inlet concentration at different reaction temperatures, respectively. As can be seen, the NO conversion increases, at a fixed space velocity, as the NO inlet concentration does. The increase of the propylene conversion is not as high as the one observed with NO, at the same experimental conditions, due to the competitive adsorption between both reactants, being NO adsorption favored with respect to the propylene one. For conversions lower than $20 \%$, a differential mode of operation can be assumed in this plug flow reactor. Furthermore, as the inlet conversion is zero, the following equation can be used to determine an apparent reaction order with respect to NO conversion:

$$
F_{N O o} \cdot \frac{X_{N O}}{W}=r_{N O}=k_{a p} \cdot C_{N O}^{n}
$$




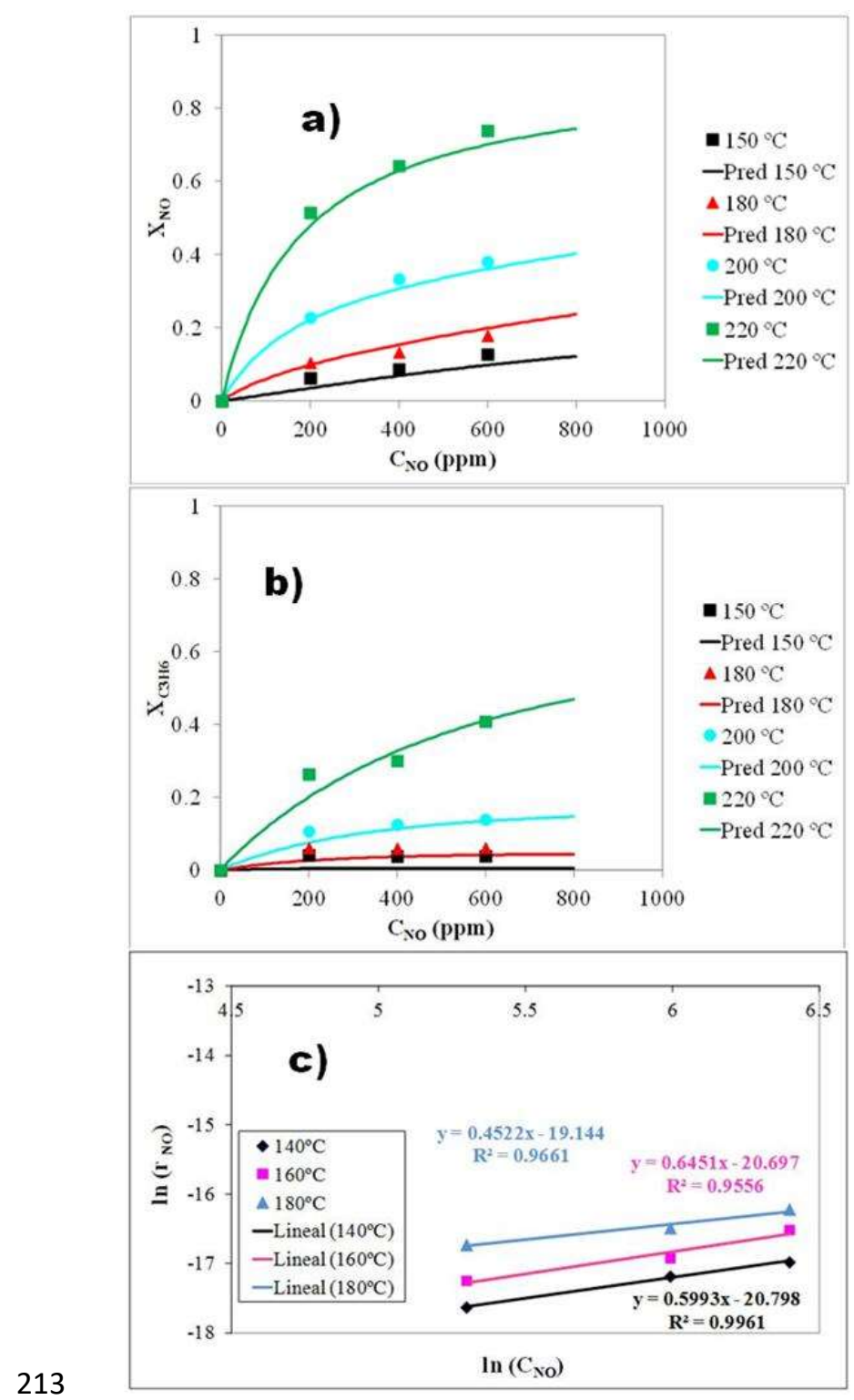

214 Figure 4. a-b) $\mathrm{NO}$ and $\mathrm{C}_{3} \mathrm{H}_{6}$ conversion as a function of $\mathrm{NO}$ inlet concentration,

215 respectively, with 1500 ppmv $_{3} \mathrm{H}_{6}$ and $3 \% \mathrm{O}_{2}$, at different reaction temperatures, and at 216 fixed $\mathrm{W} / \mathrm{F}_{\mathrm{NO}}=1.92 \mathrm{~g} \cdot \mathrm{s} / \mu \mathrm{mol}$ (symbols: experimental data; solid lines: predicted data);

217 c) Natural logarithm of the NO reaction rate as a function of the logarithm of the NO 218 inlet concentration.

220 Figure 4.c represents the natural logarithm of the NO reaction rate as a function of the 221 logarithm of the NO inlet concentration. The apparent reaction orders were found to be 
approximately 0.5 with respect to $\mathrm{NO}$ concentration, at the different temperatures evaluated. This half-order dependence suggests that the dissociative adsorption of NO must be probably involved in the reaction mechanism with this catalyst, under these conditions (temperatures lower than the one needed to reach the maximum NO conversion), in agreement with the redox mechanism proposed by Burch et al. $[5,8,9]$.

\subsection{Influence of $\mathrm{C}_{3} \mathrm{H}_{6}$ concentration on $\mathrm{NO}$ reduction}

The influence of $\mathrm{C}_{3} \mathrm{H}_{6}$ concentration on $\mathrm{NO}$ reduction was analyzed by varying $\mathrm{C}_{3} \mathrm{H}_{6}$ concentration from 200 to 1500 ppmv, with 200 ppmv NO and $3 \% \mathrm{O}_{2}$, at different reaction temperatures and at fixed $\mathrm{W} / \mathrm{F}_{\mathrm{NO}}=2.88 \mathrm{~g} \cdot \mathrm{s} / \mu \mathrm{mol}$. NO conversions as a function of the reaction temperature at different $\mathrm{C}_{3} \mathrm{H}_{6}$ concentrations are shown in Figure 5.a. The results clearly indicated that NO reaction is favored at higher propylene concentrations. Denton et al. (2001) reported that NO reduction strongly depends upon the $\theta_{\mathrm{HC}} / \theta_{\mathrm{O}}$ ratio. For $\mathrm{NO}$ to be reduced, $\theta_{\mathrm{HC}}$ must be high enough to protect the surface from oxidation by $\mathrm{O}_{2}$ and to permit $\mathrm{NO}$ adsorption [23]. Besides, the presence of propylene may be considered to inhibit the surface oxidation of $\mathrm{NO}$ to $\mathrm{NO}_{2}$ $[3,17,18,19]$. In this sense, $\mathrm{NO}$ conversion with 200 ppmv $\mathrm{C}_{3} \mathrm{H}_{6}$ at $220{ }^{\circ} \mathrm{C}$ was $28.6 \%$, being the selectivity to $\mathrm{NO}_{2}$ approximately $12 \%$. However, the NO conversion with 800 ppmv $\mathrm{C}_{3} \mathrm{H}_{6}$, at the same reaction temperature, was $64.2 \%$, obtaining in this case, a selectivity value to $\mathrm{NO}_{2}$ lower than $2 \%$. The rest was converted to $\mathrm{N}_{2}$. With $1500 \mathrm{ppmv}$ $\mathrm{C}_{3} \mathrm{H}_{6}$, the selectivity to $\mathrm{NO}_{2}$ was negligible. In contrast, all $\mathrm{NO}$ converted was selectively reduced to $\mathrm{N}_{2}$. All these results suggest that $\mathrm{NO}$ to $\mathrm{C}_{3} \mathrm{H}_{6}$ molar ratios higher than one must be used to obtain a high and selective $\mathrm{NO}$ reduction to $\mathrm{N}_{2}$. In agreement with these results, Denton et al. (2001) observed that $\mathrm{N}_{2}$ selectivity is also strongly enhanced by the increase of $\mathrm{C}_{3} \mathrm{H}_{6}$ inlet concentration [23]. 


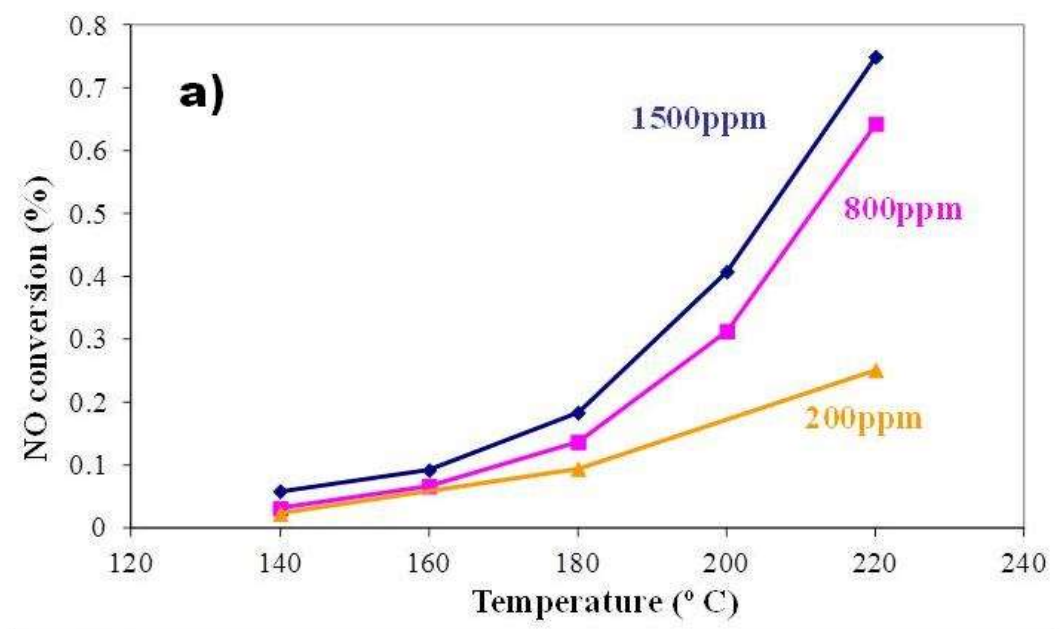

246

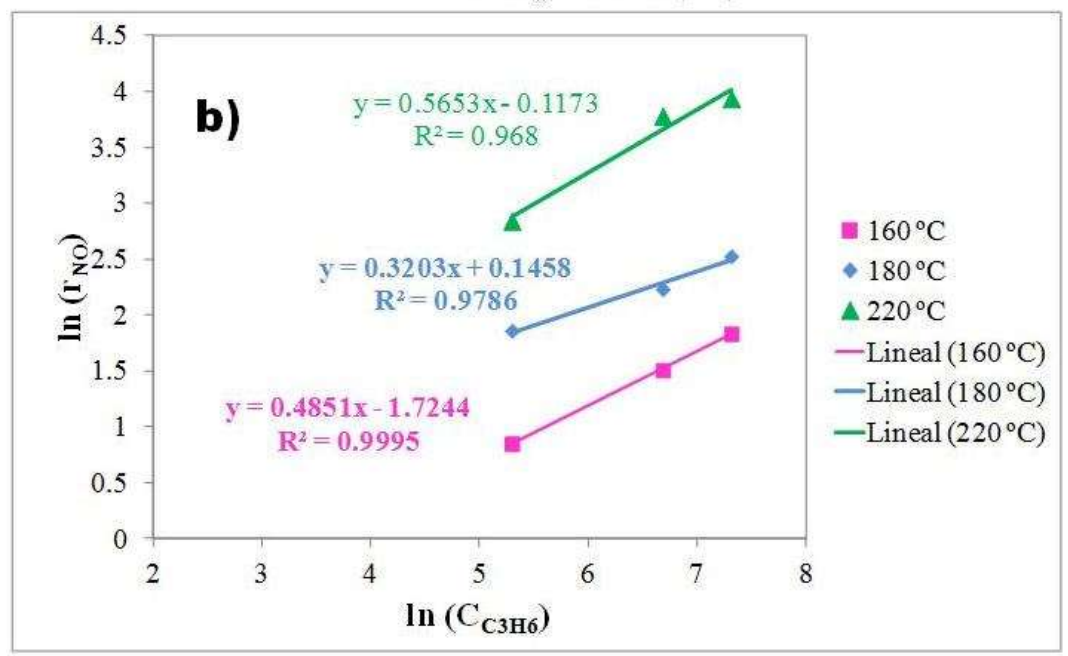

247 Figure 5. a) $\mathrm{NO}$ conversions as a function of the reaction temperature at different $\mathrm{C}_{3} \mathrm{H}_{6}$ 248 concentrations, with $200 \mathrm{ppmv} \mathrm{NO}$ and $3 \% \mathrm{O}_{2}$, and at fixed $\mathrm{W} / \mathrm{F}_{\mathrm{NO}}=2.88 \mathrm{~g} \cdot \mathrm{s} / \mu \mathrm{mol} . \mathrm{b}$ )

249 Natural logarithm of the NO reaction rate as a function of the logarithm of the $\mathrm{C}_{3} \mathrm{H}_{6}$ 250 inlet concentration.

252 To evaluate the dependence of $\mathrm{NO}$ reduction rate on $\mathrm{C}_{3} \mathrm{H}_{6}$ concentration, the natural

253 logarithm of the NO reaction rate as a function of the logarithm of the $\mathrm{C}_{3} \mathrm{H}_{6}$ inlet

254 concentration at different reaction temperatures, was represented in Figure 5.b. Half-

255 order dependence with respect to $\mathrm{C}_{3} \mathrm{H}_{6}$ inlet concentration was also observed, which can

256 be associated to the activation of the reductant by dissociative adsorption. These results 
257 are also in concordance with the formation of a carbonaceous intermediate on the active

258 Pt sites that can react with NO.

\section{3.3. Influence of $\mathrm{NO}$ concentration on $\mathrm{C}_{3} \mathrm{H}_{6}$ oxidation}

260 The range of application of this kind of catalyst strongly depends on its ability to

261 perform the activation (oxidation) of the reductant. Therefore, it is quite important to

262 analyze the behavior of the catalyst with respect to the reducing agent. For this goal, the

263 oxidation of propylene was tested with this catalyst at different propylene

264 concentrations in the presence and absence of NO. Figure 6.a collects the propylene

265 conversions as a function of the reaction temperature with different inlet concentrations,

266 but in these experiments $\mathrm{W} / \mathrm{F}_{\mathrm{C} 3 \mathrm{H} 6}$ was not constant. As can be seen, this catalyst is very

267 active for the propylene oxidation at the temperature range studied, obtaining a total

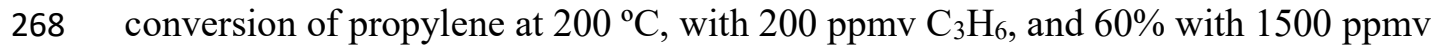

$269 \mathrm{C}_{3} \mathrm{H}_{6}$. The addition of only 200 ppmv NO shifted the oxidation curve to higher

270 temperatures; in this case, the temperature must be increased about $40{ }^{\circ} \mathrm{C}$ to observe the

271 same propylene conversion. Some authors pointed out that $\mathrm{C}_{3} \mathrm{H}_{6}, \mathrm{NO}$, and $\mathrm{O}_{2}$ are

272 adsorbed on the same type of Pt adsorption sites [21]. So, it seems that this inhibition

273 may be directly related to active site occupation by atomic N produced by NO

274 dissociation and/or adsorbed nondissociated NO molecules. In this case, NO surface

275 coverage on the Pt surface must be higher than the one corresponding to $\mathrm{O}_{2}$, thus

276 decreasing the probability of propylene combustion $[3,22]$. 

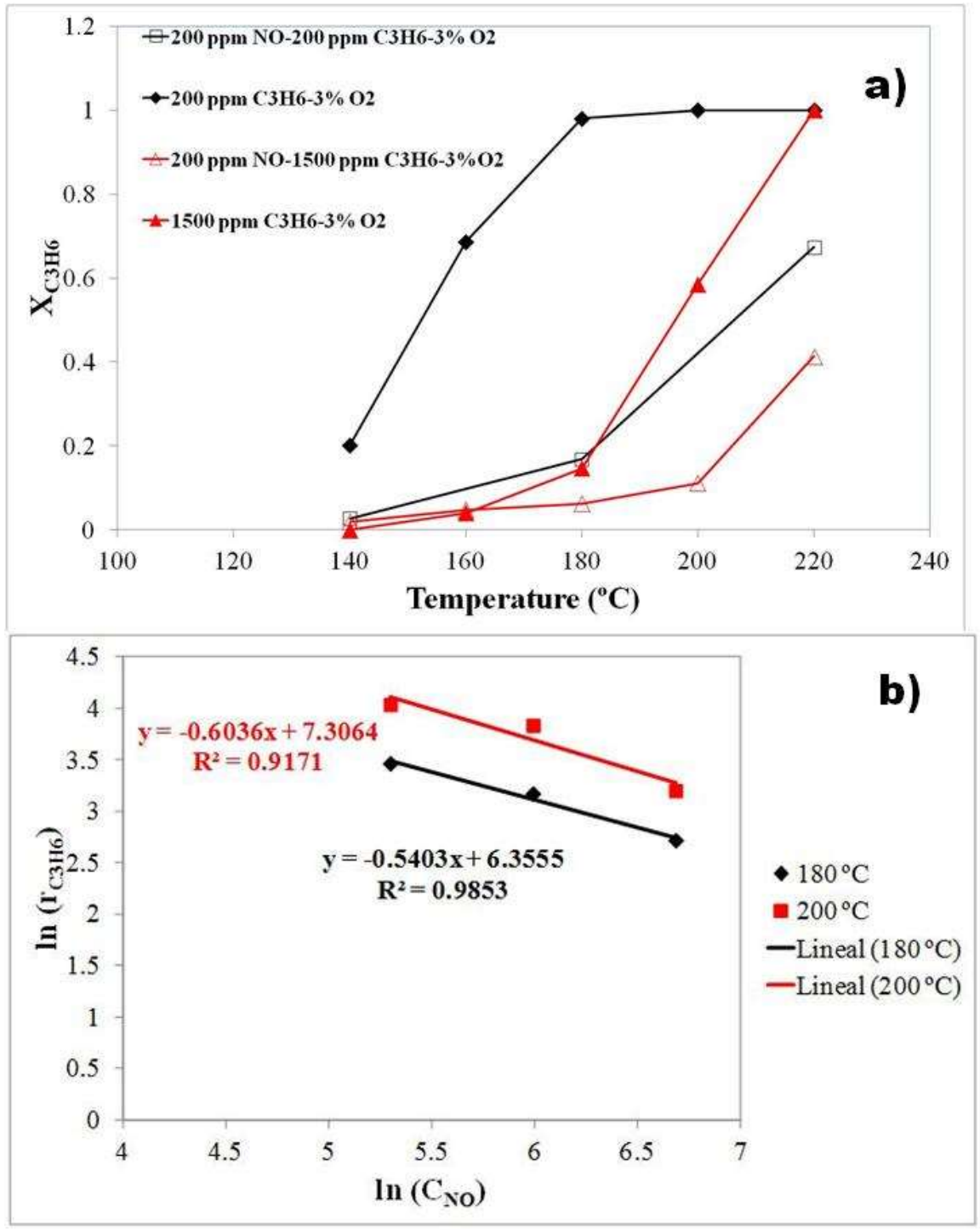

Figure 6. a) Propylene conversions as a function of reaction temperature at different inlet concentrations, with 200 ppmv $\mathrm{NO}$ and $3 \% \mathrm{O}_{2}$, and at fixed $\mathrm{W} / \mathrm{F}_{\mathrm{NO}}=2.88$ $\mathrm{g} \cdot \mathrm{s} / \mu \mathrm{mol}$. b) Natural logarithm of the $\mathrm{C}_{3} \mathrm{H}_{6}$ reaction rate as a function of the logarithm of the NO inlet concentration, at fixed $\mathrm{W} / \mathrm{F}_{\mathrm{C} 3 \mathrm{H} 6}=0.38 \mathrm{~g} \cdot \mathrm{s} / \mu \mathrm{mol}$.

\section{To study how the NO concentration affects to the rate expression of propylene} oxidation, $\mathrm{C}_{3} \mathrm{H}_{6}$ inlet concentration was fixed to 1500 ppmv and $\mathrm{NO}$ concentration was varied from 200 to $800 \mathrm{ppmv}$, with $3 \% \mathrm{O}_{2}$, at different reaction temperatures( $\mathrm{W} / \mathrm{F}_{\mathrm{C} 3 \mathrm{H} 6}=$ $0.38 \mathrm{~g} \cdot \mathrm{s} / \mu \mathrm{mol})$. Figure 6.b. shows the natural logarithm of the $\mathrm{C}_{3} \mathrm{H}_{6}$ reaction rate as a 
287 function of the logarithm of the NO inlet concentration, at different reaction

288 temperatures. As can be observed, a negative half-order term with respect to NO was

289 obtained at these experimental conditions. These results also support the partial

290 inhibition of the propylene oxidation due to the possible presence of strongly (and

291 apparently dissociatively) adsorbed NO, in agreement with the results reported by

292 Nikolopoulos et al. [23].

\subsection{Influence of $\mathrm{N}_{2} \mathrm{O}$ concentration on $\mathrm{NO}$ reduction}

294 One of the main drawbacks reported in the literature for platinum catalysts is the

295 formation of $\mathrm{N}_{2} \mathrm{O}$. Its formation during $\mathrm{NOx}$ SCR is mainly associated to the reaction

296 between adsorbed N (derived from the dissociative adsorption of NO) and NO

297 molecularly adsorbed [11,17,21,22]. However, some authors proposed that $\mathrm{N}_{2} \mathrm{O}$ is an

298 intermediate for $\mathrm{N}_{2}$ formation [22].

299 A negligible outlet gas concentration of $\mathrm{N}_{2} \mathrm{O}$ was observed with this catalyst at the

300 experimental conditions studied, in agreement with the results observed by Yang and Jung using $\mathrm{H}_{2}$ as reducing agent. These authors found that only $\mathrm{N}_{2} \mathrm{O}$ was formed at low temperatures, meanwhile the formation of $\mathrm{N}_{2}$ was predominant at temperatures over 80 ${ }^{\circ} \mathrm{C}[24]$.

This finding can be associated to two different hypotheses: a) the dissociative adsorption of NO is so fast, that the presence of NO molecularly adsorbed is negligible; b) if $\mathrm{N}_{2} \mathrm{O}$ is an intermediate for $\mathrm{N}_{2}$ formation, the transformation reaction of $\mathrm{N}_{2} \mathrm{O}$ to $\mathrm{N}_{2}$ must be very quick. To analyze the role of $\mathrm{N}_{2} \mathrm{O}$, two different kinds of experiments were carried out. Firstly, the reaction of $\mathrm{N}_{2} \mathrm{O}$ was evaluated at several conditions: with only 200 ppmv $\mathrm{N}_{2} \mathrm{O}$, with 200 ppmv $\mathrm{N}_{2} \mathrm{O}$ and 3\% $\mathrm{O}_{2}$ and with 200 ppmv $\mathrm{N}_{2} \mathrm{O}, 1500$ 
311 conversion of $\mathrm{N}_{2} \mathrm{O}$ was negligible at these conditions. In this sense, Konsolakis et al.

312 (2012) observed that $\mathrm{N}_{2} \mathrm{O}$ reacted at temperatures higher than $300{ }^{\circ} \mathrm{C}[25]$.

313 On the other hand, an experiment with 200 ppmv NO, 200 ppmv $\mathrm{N}_{2} \mathrm{O}, 1500$ ppmv $\mathrm{C}_{3} \mathrm{H}_{6}$

314 and $3 \% \mathrm{O}_{2}$ was also performed. Figure 7 shows a comparison between the NO

315 conversion as a function of the reaction temperature in the presence and absence of

$316 \mathrm{~N}_{2} \mathrm{O}$. The profile was very similar in both cases, which seems to indicate that the

317 formation of $\mathrm{N}_{2}$ does not take place via $\mathrm{N}_{2} \mathrm{O}$ intermediate.

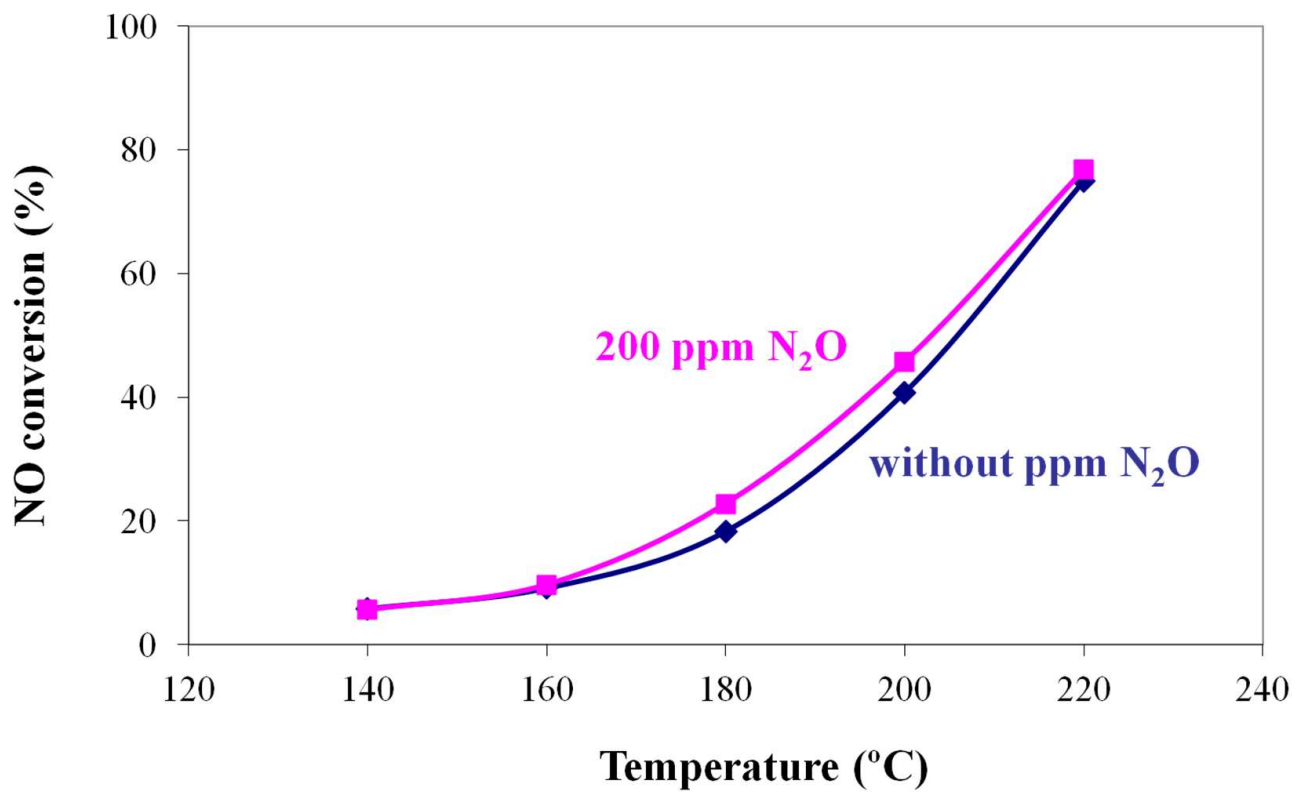

319 Figure 7. NO conversion as a function of the reaction temperature in the presence and absence of 200 ppmv $\mathrm{N}_{2} \mathrm{O}$, with 200 ppmv $\mathrm{NO}, 1500$ ppmv $\mathrm{C}_{3} \mathrm{H}_{6}$ and $3 \% \mathrm{O}_{2}$.

321

322

\subsection{Role of $\mathrm{O}_{2}$ on $\mathrm{NO}$ reduction}

323 Figure 8 shows the evolution of outlet gas concentration as a function of the reaction

324 time for an experiment where the inlet gases were added sequentially. Initially, only $3 \%$

$325 \mathrm{O}_{2}$ was introduced in the reactor at $210^{\circ} \mathrm{C}$. After around $60 \mathrm{~min}$, NO diluted in $\mathrm{He}(200$

$\left.326 \mathrm{ppm}, \mathrm{W} / \mathrm{F}_{\mathrm{NO}}=2.88 \mathrm{~g} \cdot \mathrm{s} / \mu \mathrm{mol}\right)$ was added to the inlet stream and, finally, at around 120 
327 min of reaction time, $\mathrm{C}_{3} \mathrm{H}_{6}(1500 \mathrm{ppm})$ was also introduced. Some differences can be

noticed by comparing the second step of this figure with the one shown in Figure 2, corresponding to the oxidation of NO. The NO conversion is the same in both cases (48\%), but a prompt evolution of $\mathrm{NO}_{2}$ can be observed in Figure 2. On the contrary, a certain induction time in the formation of $\mathrm{NO}_{2}$ appears in Figure 8 and the time required to achieve a pseudo steady state in this last experiment is much longer than the one represented in Figure 2, where the steady state is immediately reached.

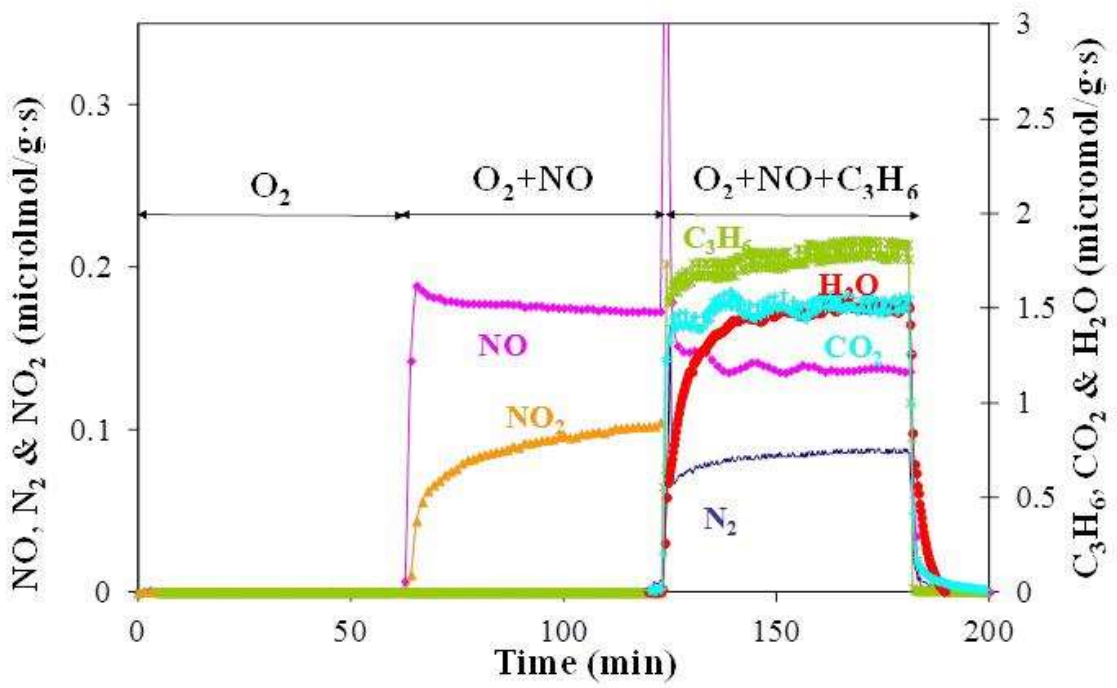

Figure 8. Evolution of outlet gas concentration as a function of reaction time, with $3 \% \mathrm{v}$ $\mathrm{O}_{2}, 200 \mathrm{ppm} v \mathrm{NO}$ and $1500 \mathrm{ppm}_{\mathrm{v}} \mathrm{C}_{3} \mathrm{H}_{6}$, at $210^{\circ} \mathrm{C}, \mathrm{W} / \mathrm{F}_{\mathrm{NO}}=2.88 \mathrm{~g} \cdot \mathrm{s} / \mu \mathrm{mol}$.

With the sequence $\mathrm{NO}-\mathrm{NO}+\mathrm{O}_{2}$, the NO surface coverage must be quite high and the addition of oxygen produces the rapid reaction to $\mathrm{NO}_{2}$. In contrast, the previous addition of $\mathrm{O}_{2}$ seems to imply $\mathrm{O}_{2}$ adsorption and when $\mathrm{NO}$ is added to the inlet stream, this must be then adsorbed, probably, displacing oxygen from the Pt active sites. The long time required to achieve a pseudo steady state in this case seems to indicate that a large NO surface coverage is required for its oxidation to take place and that the surface 
population of $\mathrm{O}_{2}$ must be significantly decreased. On the other hand, it is important to mention that once the steady state is reached, only $65 \%$ of the NO converted evolved as

$346 \mathrm{NO}_{2}$ at the outlet stream, suggesting either the partial adsorption of $\mathrm{NO}$ or the formed

$347 \mathrm{NO}_{2}$. In this sense, Khosravi et al. (2014) analyzed different kinetic models reported in

348 the literature for the oxidation of NO, preferentially based on Eley-Rideal models, and

349 even including the possible inhibition effect of the $\mathrm{NO}_{2}$ adsorbed [26]. Similarly,

350 Denton et al. also observed that $\mathrm{NO}_{2}$ reacts with propylene to only $\mathrm{NO}$ nor $\mathrm{N}_{2}$ or $\mathrm{N}_{2} \mathrm{O}$

351 [22]. Therefore, these results could indicate that the large initial evolution of NO (see

352 Figure 8) when propylene was added is related to the reaction between adsorbed $\mathrm{NO}_{2}$

353 and propylene. Then, when steady state is reached, the preferential formation of $\mathrm{N}_{2}$ is

354 detected.

In order to clarify if there is a competition between $\mathrm{NO}$ and $\mathrm{O}_{2}$ with our catalyst for the active sites with a preferential adsorption of $\mathrm{NO}$ or if $\mathrm{O}_{2}$ is completely displaced by $\mathrm{NO}$ at this temperature, different experiments were performed. Firstly, the catalyst was treated with a stream containing only $\mathrm{NO}(200 \mathrm{ppmv})$ at $200{ }^{\circ} \mathrm{C}$, then a temperature programmed desorption (TPD) was carried out up to $500^{\circ} \mathrm{C}$. All NO adsorbed was desorbed at the same temperature (physisorption), without any evolution during TPD.

361 The same experiment was carried out but using $3 \% \mathrm{O}_{2}$, at the same temperature, and, in the same way, the oxygen adsorbed was evolved during the desorption step, with a negligible evolution during the TPD. The adsorption of $\mathrm{O}_{2}$ was also analyzed at $260{ }^{\circ} \mathrm{C}$; the adsorbed amounts were quite similar at 200 and $260^{\circ} \mathrm{C}$, and in neither of both experiments the evolution of $\mathrm{O}_{2}$ was detected during TPD.

366 The same experiment was carried out but only using $3 \% \mathrm{O}_{2}$, at $200{ }^{\circ} \mathrm{C}$ and $260{ }^{\circ} \mathrm{C}$. The 367 oxygen adsorbed was similar in both experiments and all of it evolved during the 368 desorption step, with a negligible evolution during the TPD. 
369 In another test, the $\mathrm{NO}$ adsorption was also evaluated at $200{ }^{\circ} \mathrm{C}$, but in this case, the 370 catalyst used was previously reacted with $\mathrm{NO}^{-} \mathrm{O}_{2}-\mathrm{C}_{3} \mathrm{H}_{6}$ at $260{ }^{\circ} \mathrm{C}$. The corresponding

371 results are shown in Figure 9. As can be seen, an important and exponential $\mathrm{O}_{2}$

372 evolution was observed during the treatment with NO, which takes place

373 simultaneously to a decrease of the NO concentration. Furthermore, a low formation of

$374 \mathrm{NO}_{2}$ can be also noticed. The adsorption of oxygen seems to be very stable at the

375 highest temperature range. During the desorption step, all NO adsorbed was completely

376 desorbed. These results suggest that $\mathrm{O}_{2}$ is greatly adsorbed on Pt surface in the absence

377 of other gases in the inlet stream or at high temperatures (temperatures higher than the

378 one at which the maximum NO conversion is obtained, Tmax). The addition of NO at

379 low temperatures produces the displacement of oxygen from the Pt active sites.

380

381

382

383

384

385

386

387

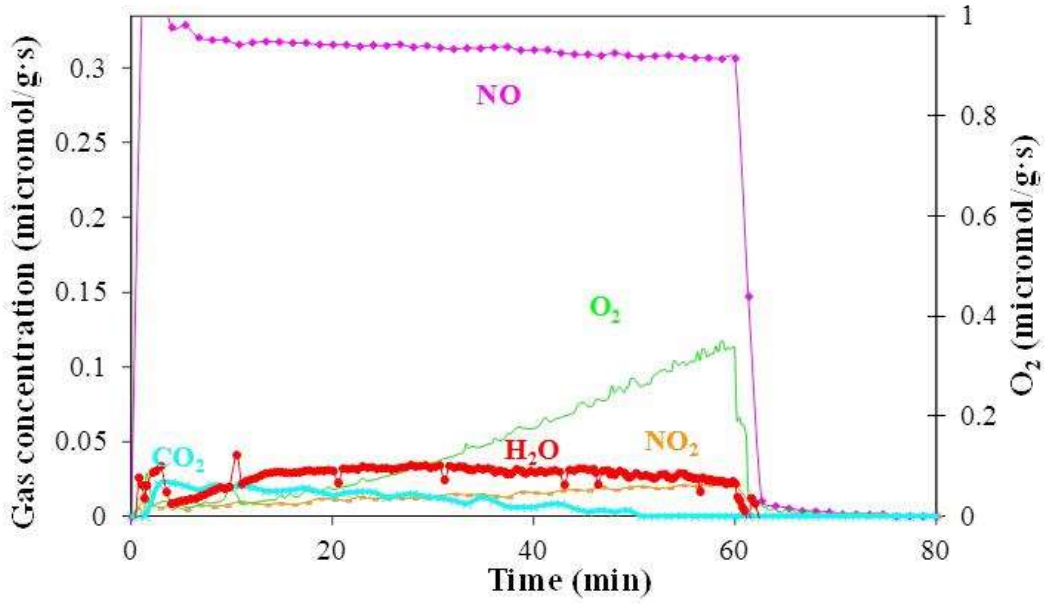

Figure 9. Evolution of outlet gas concentration as a function of reaction time, with 200 ppmV NO, at $210^{\circ} \mathrm{C}$, after reacting with $\mathrm{NO}-\mathrm{O}_{2}-\mathrm{C}_{3} \mathrm{H}_{6}$ at $260^{\circ} \mathrm{C}$.

Finally, the catalyst was treated with $3 \% \mathrm{O}_{2}$ at $260{ }^{\circ} \mathrm{C}$ for $1 \mathrm{~h}$ and then the oxygen was desorbed at the same temperature. At this temperature, a stream containing $1500 \mathrm{ppmv}$ $\mathrm{C}_{3} \mathrm{H}_{6}$ was fed for $1 \mathrm{~h}$, and subsequently desorbed. Then, the catalyst was cooled to 200 ${ }^{\circ} \mathrm{C}$ and followed by a TPD up to $500{ }^{\circ} \mathrm{C}$. The adsorption of $\mathrm{O}_{2}$ was close to $6 \mathrm{mmol} / \mathrm{g}$. 
388 During the desorption step at $260{ }^{\circ} \mathrm{C}$, the amount of $\mathrm{O}_{2}$ desorbed (corresponding to

389 physisorbed $\mathrm{O}_{2}$ ) was $5.66 \mathrm{mmol} / \mathrm{g}$. So, $0.34 \mathrm{mmol} / \mathrm{g}$ of $\mathrm{O}_{2}$ must remain strongly

390 adsorbed on the catalyst surface. With the addition of propylene at $200{ }^{\circ} \mathrm{C}$, a low

391 formation of $\mathrm{CO}_{2}$ can be observed $(0.035 \mathrm{mmol} / \mathrm{g})$. The evolution of oxygen was not

392 observed, in this case. Therefore, it seems that the oxidation of propylene is favored,

393 instead of the displacement of oxygen from the active sites, at this high temperature.

394 During the cooling step, an additional $\mathrm{CO}_{2}$ evolution was also detected $(0.28 \mathrm{mmol} / \mathrm{g})$,

395 suggesting that all $\mathrm{O}_{2}$ adsorbed was available for the reductant oxidation. In agreement

396 with these results, Garcia Cortes et al. (2007) reported that the surface coverage of

397 oxygen is very low and there exists a direct competition between $\mathrm{NO}$ and $\mathrm{O}_{2}$ for $\mathrm{Pt}$

398 adsorption sites, being favorable to NO, at temperatures below Tmax. However, the

399 catalyst surface is mainly covered by oxygen species at temperatures higher than Tmax

400 [19]. In this line, $\mathrm{Li}$ et al. also found a competitive adsorption between $\mathrm{NO}$ and $\mathrm{O}_{2}$ with

401 a Pt/SAPO-34 catalyst, but using CO as reducing agent [27].

\section{3.6. Reaction mechanism}

\section{3.6.1. NO oxidation}

404 This reaction is exothermic and is limited by its equilibrium at high temperatures. There

405 are many works in the literature which deals with the oxidation of NO on platinum

406 catalyst. An Eley-Rideal-type mechanism involving dissociative adsorption of $\mathrm{O}_{2}$ and

407 reaction of NO from gas phase is mostly used to model the NO oxidation reaction on $\mathrm{Pt}$

408 catalysts [28-30]. However, the results obtained in the present work by adding the gases

409 sequentially seem to indicate that a certain NO surface coverage is required for the

410 oxidation reaction to take place. In this sense, some authors have found that a 
411 Langmuir-Hinshelwood model is more adequate to model the NO oxidation reaction

$412[31,32]$. Therefore, the following reactions are proposed to describe the NO oxidation:

$413 *+N O \stackrel{K_{N O}}{\longleftrightarrow} * N O$

$414 \quad *+\mathrm{O}_{2} \stackrel{K_{O 2}}{\longleftrightarrow} * \mathrm{O}_{2}$

$415 *+* O_{2} \stackrel{K_{O 2 d}}{\longleftrightarrow} 2 * O$

$416 * \mathrm{NO}+* \mathrm{O} \stackrel{k_{\mathrm{NO} 2}}{\longrightarrow} * \mathrm{NO}_{2}+*$

$417 \quad * \mathrm{NO}_{2} \stackrel{\mathrm{K}_{\mathrm{NO} 2}}{\longleftrightarrow} \mathrm{NO}_{2}+*$

418 Reaction 2 makes reference to the equilibrium adsorption of $\mathrm{NO} . \mathrm{O}_{2}$ adsorption is

419 assumed to proceed through a molecular precursor (reaction 3), followed by the

420 dissociation of the precursor to atomic oxygen (reaction 4), due to oxygen dissociation

421 on Pt surface proceeds via a precursor-mediated reaction path [31]. Reaction 5 considers

422 the surface reaction between $\mathrm{NO}$ adsorbed and dissociative oxygen adsorbed to form

$423 \mathrm{NO}_{2}$. The equilibrium adsorption of the $\mathrm{NO}_{2}$ formed is represented in Reaction 6 . This

424 last reaction is supported by the work of Mulla et al. (2006). They included a certain

425 inhibition effect in the kinetic model due to the adsorbed $\mathrm{NO}_{2}$, which partially inhibited

426 the Pt active sites [32].

427 Some authors reported that adsorbed NO predominantly covers the catalyst surface at

428 low temperatures $\left(<150^{\circ} \mathrm{C}\right)$, which is due to its high sticking coefficient on Pt. As the

429 temperature is increased, the surface becomes predominantly covered with $\mathrm{O}$ until, at a

430 very high temperature $\left(\sim 400^{\circ} \mathrm{C}\right)$, adsorbed $\mathrm{O}$ starts desorbing as $\mathrm{O}_{2}$, which results in an

431 increase in the vacant site coverage [31]. 
433 As aforementioned, two main reaction mechanisms are reported in the literature to

434 describe the NO reduction in the presence of propylene and oxygen. The first one

435 involves production of molecular nitrogen through NO dissociative adsorption via a

436 redox mechanism. The other mechanism proposes, in a simplified way, that the

437 activated hydrocarbon react with $\mathrm{NO}$ or $\mathrm{NO}_{2}$ to finally decomposes to $\mathrm{N}_{2}$ or $\mathrm{N}_{2} \mathrm{O}$.

438 Based on the results previously commented, the following reactions can be also

439 considered in the mechanism for the low temperature SCR:

$440 *+* N O \stackrel{K_{N O d}}{\longleftrightarrow} * N+* O$

$441 \quad *+\mathrm{C}_{3} \mathrm{H}_{6} \stackrel{K_{\mathrm{C} 3 \mathrm{H}}}{\longleftrightarrow} * \mathrm{C}_{3} \mathrm{H}_{6}$

$442 * \mathrm{C}_{3} \mathrm{H}_{6}+* \mathrm{O} \stackrel{k_{C 3 H 6}}{\longrightarrow} * \mathrm{C}_{3} \mathrm{H}_{6} \mathrm{O}+*$

$443 * \mathrm{C}_{3} \mathrm{H}_{6} \mathrm{O}+4 \mathrm{O}_{2} \stackrel{k_{33 \mathrm{H} 6}^{\prime}}{\longrightarrow} 3 \mathrm{CO}_{2}+3 \mathrm{H}_{2} \mathrm{O}+*$

$444 * N+* N \stackrel{k_{N 2}}{\longrightarrow} N_{2}+2 *$

$445 \quad * \mathrm{C}_{3} \mathrm{H}_{6} \mathrm{O}+* \mathrm{NO} \stackrel{\mathrm{k}_{3}^{\prime \prime} 6}{\longrightarrow} * \mathrm{C}_{3} \mathrm{H}_{6} \mathrm{NO}_{2}+*$

$446 * \mathrm{C}_{3} \mathrm{H}_{6} \mathrm{NO}_{2}+* \mathrm{NO}+3 \mathrm{O}_{2} \stackrel{k_{\mathrm{C} 3 \mathrm{H} 6}^{\prime \prime \prime}}{\longrightarrow} \mathrm{N}_{2}+3 \mathrm{CO}_{2}+3 \mathrm{H}_{2} \mathrm{O}+2 *$

447 The three reactants $\left(\mathrm{C}_{3} \mathrm{H}_{6}, \mathrm{NO}\right.$, and $\left.\mathrm{O}_{2}\right)$ are suggested to be adsorbed on the same type

448 of Pt adsorption sites (denoted as *). However, in this case, the kinetic constants of

449 reactions (3) and (4), corresponding to $\mathrm{O}_{2}$ adsorption, must be significantly decreased at

450 temperatures lower than Tmax, due to the surface coverage of oxygen is rather low at

451 these temperatures. Reactions (5) and (6) are not going to be taken into account in the 
452 kinetic model, due to the fact that the formation of $\mathrm{NO}_{2}$ in the presence of propylene is

453 lower than $5 \%$ at best, and besides, its reduction produces the formation of NO nor $\mathrm{N}_{2}$

454 or $\mathrm{N}_{2} \mathrm{O}[22]$.

455 A half-order dependence with respect to NO was observed for the NO reduction rate,

456 what suggests that the dissociative adsorption of NO must be probably involved in the

457 reaction mechanism, under the experimental conditions tested (temperatures lower than

458 the one needed to reach the maximum NO conversion). This mechanism is represented

459 by reactions (7) and (11). Nevertheless, the possibility of a mechanism based on the

460 activation of the hydrocarbon cannot be completely ruled out. Therefore, it has also

461 been considered in reactions (12) and (13), as pointed by Zheng et al. [33].

462 On the other hand, the absence of $\mathrm{N}_{2} \mathrm{O}$ at the outlet stream can indicate the low presence

463 of NO molecularly adsorbed on the catalyst surface. Furthermore, it is also observed

464 that the formation of $\mathrm{N}_{2}$ does not take place via $\mathrm{N}_{2} \mathrm{O}$ intermediate. So, the formation of

$465 \mathrm{~N}_{2} \mathrm{O}$ has not been considered in this reaction mechanism.

466 With regard to the role of oxygen, Captain et al. (2000) also reported that molecular

467 oxygen could be involved in the reaction pathway [11] and Nikolopoulos et al. (1990)

468 found a first-order dependence of $\mathrm{NO}$ reduction and $\mathrm{C}_{3} \mathrm{H}_{6}$ oxidation on $\mathrm{O}_{2}$ for

$469 \mathrm{Pt} /$ alumina, suggesting the possibility of direct participation of $\mathrm{O}_{2}$ from the gas phase in

470 the activation of the reductant or the removal of carbonaceous deposits [23]. In our case,

471 the reduction of NO with propylene in the absence of oxygen was negligible, and only

472 with the addition of oxygen was observed a significant NO conversion [15]. Besides,

473 the results above described suggest that the surface coverage of oxygen at temperatures

474 lower than Tmax is very low, so, the participation of oxygen from the gas phase in the 
475 NO reduction has been considered in this reaction mechanism by reactions (10) and 476 (13).

477 Finally, reaction (9) and (10) make reference to the own oxidation of propylene in the 478 presence of oxygen. Although this oxidation is partially inhibited in the presence of NO, 479 the amount of propylene oxidized is higher than the amount of NO reduced. Therefore, 480 they must be included in the mechanism. Some authors even suggested that in the lower 481 temperature region the activation of the hydrocarbon appears to be the kinetically 482 significant step. Such a claim is supported by the observed delay in the hydrocarbon 483 light-off in the presence of NO, the close proximity of the ascending part of the NO 484 reduction curves and the corresponding hydrocarbon oxidation curves, and the coupling 485 between the points of maximum NO conversion and complete hydrocarbon oxidation $486[8]$.

487 On the other hand, it is important to clarify that reaction (13) is not a direct reaction, but 488 it involves the formation of different intermediates. However, no physical evidences of 489 the possible intermediates are observed in these experiments, and the literature is not 490 clear about this aspect. For this reason and for the sake of simplicity, this reaction has 491 been considered by one unique step. However, a possible reaction pathway could be as 492 follows:

$* \mathrm{C}_{3} \mathrm{H}_{6} \mathrm{NO}_{2}+* \mathrm{NO} \rightarrow \mathrm{C}_{2} \mathrm{H}_{6}+\mathrm{N}_{2}+\mathrm{CO}_{2}+* \mathrm{O}$

$494 \mathrm{C}_{2} \mathrm{H}_{6}+* \mathrm{O} \rightarrow \mathrm{C}_{2} \mathrm{H}_{4}+\mathrm{H}_{2} \mathrm{O}+*$

495

$\mathrm{C}_{2} \mathrm{H}_{4}+\mathrm{O}_{2} \rightarrow \mathrm{CH}_{4}+\mathrm{CO}_{2}$

496

$$
\mathrm{CH}_{4}+* \mathrm{O} \rightarrow * \mathrm{CH}_{2}+\mathrm{H}_{2} \mathrm{O}
$$


$497 * \mathrm{CH}_{2}+* \mathrm{O} \rightarrow * \mathrm{CH}_{2} \mathrm{O}+*$

$498 * \mathrm{CH}_{2} \mathrm{O}+\mathrm{O}_{2} \rightarrow \mathrm{H}_{2} \mathrm{O}+\mathrm{CO}_{2}+*$

499 3.6.3. Rate equations and kinetic study

500 By considering, the adsorption equilibriums of $\mathrm{NO}, \mathrm{O}_{2}$ and $\mathrm{C}_{3} \mathrm{H}_{6}$ over the platinum site

501 (reactions 3-5,8), and assuming that the surface coverage of dissociated oxygen and

502 nitrogen are the same, it can be obtained:

$503 \quad \theta_{N O}=K_{N O} \cdot C_{N O} \cdot \theta_{f}$

$504 \theta_{O_{2}}=K_{O 2} \cdot C_{O 2} \cdot \theta_{f}^{2}$

$505 \quad \theta_{C_{3} H_{6}}=K_{C_{3} H_{6}} \cdot C_{C_{3} H_{6}} \cdot \theta_{f}$

$506 \theta_{N}=\theta_{O}=\left(K_{N O d} \cdot \theta_{N O} \cdot \theta_{f}\right)^{0.5}$

507 Taking into account quasi steady-state for the formation rate of $* \mathrm{C}_{3} \mathrm{H}_{6} \mathrm{O}$ intermediate, 508 and by considering reaction (13) much faster than reaction (12), the presence of

$509 * \mathrm{C}_{3} \mathrm{H}_{6} \mathrm{NO}_{2}$ intermediate can be ruled out. So, the following expression can be drawn:

$510 \quad \theta_{C_{3} H_{6} O}=\frac{k_{C_{3} H_{6}} \cdot \theta_{C_{3} H_{6}} \cdot \theta_{O}}{k_{C_{3} H_{6}}^{\prime} \cdot C_{O 2}^{4}+k_{C_{3} H_{6}}^{\prime \prime} \cdot \theta_{N O}}$

511 Therefore, the site balance for the platinum active sites can be written as follows:

$5121=\theta_{f}+\theta_{N O}+\theta_{O_{2}}+\theta_{C_{3} H_{6}}+\theta_{N}+\theta_{O}+\theta_{O C_{3} H_{6}}$

513 Finally, it is also considered that the NO reaction rate can be expressed as a combination

514 of the contribution of the NO reduction by the redox mechanism, and by the activation

515 of the hydrocarbon with the following reaction with NO adsorbed. Meanwhile, the 
516 oxidation of propylene can be considered to take place directly by its reaction with

517 oxygen and also by its interaction with NO:

$518 r_{N O}=-k_{N 2} \cdot \theta_{N}^{2}-2 \cdot k_{C 3 H 6}^{\prime \prime} \cdot \theta_{C_{3} H_{6} O} \cdot \theta_{N O}$

$519 r_{N_{2}}=-\frac{1}{2} \cdot r_{N O}$

$520 r_{C_{3} H_{6}}=-k_{C 3 H 6}^{\prime} \cdot \theta_{C_{3} H_{6} O} \cdot C_{O 2}{ }^{4}-k_{C 3 H 6}^{\prime \prime} \cdot \theta_{C_{3} H_{6} O} \cdot \theta_{N O}$

521

522 The values obtained for the kinetics parameters and the kinetic constant values at 180

$523{ }^{\circ} \mathrm{C}$, for the NO reduction in the presence of propylene are shown in Table 1 . The

524 parameters obtained by the resolution of the model equations indicate that the redox

525 mechanism, proposed by Burch et al. $(5,8-9)$ presents a major relevance than the

526 mechanism of activation of the hydrocarbon, showing kinetic constant values at $180{ }^{\circ} \mathrm{C}$

527 at least three orders of magnitude higher for the redox mechanism than those obtained

528 for the activation of the hydrocarbon. These results are in concordance with the high

529 selectivity to $\mathrm{N}_{2}$, because the majority presence of dissociated $\mathrm{NO}$ avoids the formation

530 of $\mathrm{N}_{2} \mathrm{O}$ by the reaction of molecular $\mathrm{NO}$ with $\mathrm{N}$ dissociated from $\mathrm{NO}$.

531 Figure 4.a also represents as solid lines the estimated NO conversion as a function of

532 NO inlet concentration at different reaction temperatures and at a fixed space velocity of

$533 \mathrm{~W} / \mathrm{F}_{\mathrm{NO}}=1.92 \mathrm{~g} \cdot \mathrm{s} / \mu \mathrm{mol}$. Figure 10 shows the $\mathrm{NO}$ and $\mathrm{C}_{3} \mathrm{H}_{6}$ conversions, respectively, as

534 a function of the space-time at different reaction temperatures (NO inlet concentration $=$

$535400 \mathrm{ppm})$. The solid lines represent the $\mathrm{NO}$ and $\mathrm{C}_{3} \mathrm{H}_{6}$ conversions obtained from this

536 mechanism. The increase of the space time leads to higher conversion values. As can be

537 seen, both NO reduction and oxidation conversions are represented reasonably well by

538 the model proposed. 

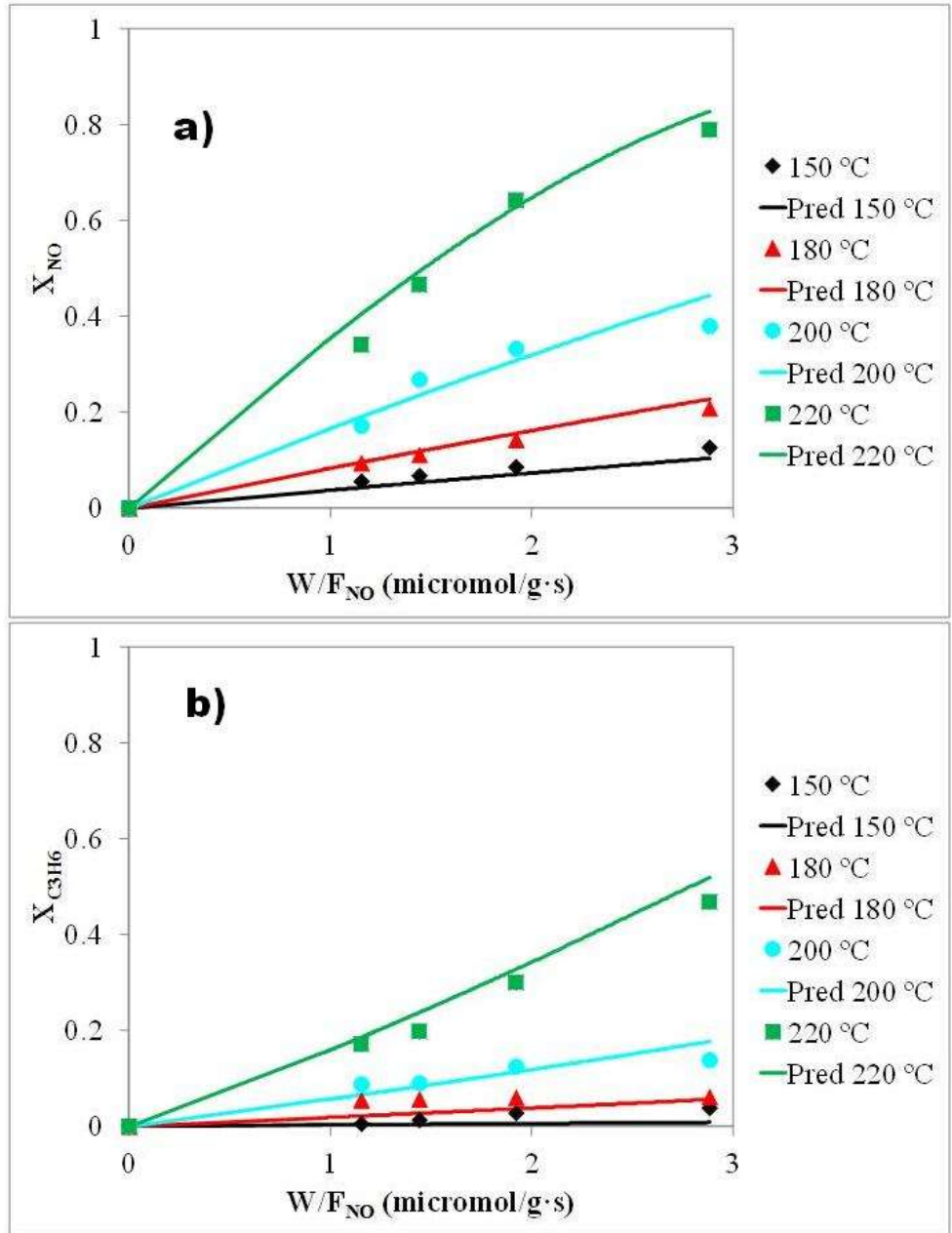

540 Figure 10. a) NO conversions as a function of the space time at different reaction

541 temperatures, with $1500 \mathrm{ppmv}_{3} \mathrm{H}_{6}$ and $3 \% \mathrm{O}_{2}$, and at fixed $\mathrm{NO}$ concentration, 400

542 ppmv (symbols: experimental data; solid lines: predicted data); b) $\mathrm{C}_{3} \mathrm{H}_{6}$ conversions as

543 a function of the space time at different reaction temperatures, with $3 \% \mathrm{O}_{2}$, and at fixed

544 NO concentration, 400 ppmv (symbols: experimental data; solid lines: predicted data).

545

546 Table 1. Kinetic and thermodynamic parameters estimated with the proposed model.

\begin{tabular}{|c|c|c|c|}
\hline & $\begin{array}{c}\text { Kinetic constant } \\
\text { value at } 180^{\circ} \mathrm{C}\end{array}$ & & \\
\hline \multirow{2}{*}{$\mathrm{K}_{\mathrm{NO}}$} & \multirow{2}{*}{$1.63 \cdot 10^{4}$} & $\mathrm{~K}_{\mathrm{oNO}}\left(\mathrm{M}^{-1}\right)$ & $1.26 \cdot 10^{2}$ \\
\cline { 3 - 4 } & \multirow{2}{*}{$2.88 \cdot 10^{3}$} & $\Delta \mathrm{H}_{\mathrm{NO}}(\mathrm{J} / \mathrm{mol})$ & $-6.11 \cdot 10^{3}$ \\
\cline { 3 - 4 } $\mathrm{K}_{\mathrm{C} 3 \mathrm{H} 6}$ & \multirow{2}{*}{1.24} & $\mathrm{~K}_{\mathrm{oC} 3 \mathrm{H} 6}\left(\mathrm{M}^{-1}\right)$ & $6.80 \cdot 10^{3}$ \\
\cline { 3 - 4 } & \multirow{2}{*}{$\mathrm{K}_{\mathrm{O} 2}$} & $\Delta \mathrm{H}_{\mathrm{C} 3 \mathrm{H} 6}(\mathrm{~J} / \mathrm{mol})$ & $-3.34 \cdot 10^{3}$ \\
\hline \multirow{2}{*}{$\mathrm{K}_{\mathrm{NOd}}$} & 10.37 & $\mathrm{~K}_{\mathrm{oO} 2}\left(\mathrm{M}^{-1}\right)$ & $9.50 \cdot 10^{-8}$ \\
\cline { 3 - 4 } & & $\Delta \mathrm{H}_{\mathrm{O} 2}(\mathrm{~J} / \mathrm{mol})$ & $-2.28 \cdot 10^{4}$ \\
\hline & & $\mathrm{K}_{\mathrm{oNOd}}(-)$ & $-2.31 \cdot 10^{-3}$ \\
\hline
\end{tabular}




\begin{tabular}{|c|c|c|c|}
\hline \multirow{2}{*}{$\mathrm{k}_{\mathrm{C} 3 \mathrm{H} 6}$} & \multirow{2}{*}{$9.35 \cdot 10^{-4}$} & $\mathrm{k}_{\mathrm{OC} 3 \mathrm{H} 6}(-)$ & $2.14 \cdot 10^{7}$ \\
\cline { 3 - 4 } & & $\mathrm{Ea}_{\mathrm{C} 3 \mathrm{H} 6}(\mathrm{~J} / \mathrm{mol})$ & $9.81 \cdot 10^{4}$ \\
\hline \multirow{2}{*}{$\mathrm{k}_{\mathrm{C} 3 \mathrm{H} 6}}$, & \multirow{2}{*}{$1.02 \cdot 10^{-5}$} & $\mathrm{k}_{\mathrm{oC} 3 \mathrm{H} 6}\left(\mathrm{~mol} \cdot \mathrm{g}^{-1} \cdot \mathrm{s}^{-1} \mathrm{M}^{-4}\right)$ & $6.77 \cdot 10^{0}$ \\
\cline { 3 - 4 } & \multirow{2}{*}{0.062} & $\mathrm{Ea}_{\mathrm{C} 3 \mathrm{H} 6}(\mathrm{~J} / \mathrm{mol})$ & $4.61 \cdot 10^{4}$ \\
\hline \multirow{2}{*}{$\mathrm{k}_{\mathrm{N} 2}$} & \multirow{2}{*}{$1.64 \cdot 10^{-6}$} & $\mathrm{k}_{\mathrm{oN} 2}\left(\mathrm{~mol} \cdot \mathrm{g}^{-1} \cdot \mathrm{s}^{-1}\right)$ & $3.38 \cdot 10^{-2}$ \\
\cline { 3 - 4 } & & $\mathrm{Ea}_{\mathrm{NC} 2}\left(\mathrm{~J} / \mathrm{mol} 6^{\prime}\left(\mathrm{mol} \cdot \mathrm{g}^{-1} \cdot \mathrm{s}^{-1}\right)\right.$ & $4.26 \cdot 10^{4}$ \\
\cline { 3 - 4 } & & $\mathrm{Ea}_{\mathrm{C} 3 \mathrm{H} 6},(\mathrm{~J} / \mathrm{mol})$ & $1.74 \cdot 10^{3}$ \\
\hline \multirow{2}{*}{$\mathrm{k}_{\mathrm{C} 3 \mathrm{H} 6}}$, & & &
\end{tabular}

548

549 CONCLUSIONS

550 The kinetic study for the NO reduction, in the presence of propylene as reductant agent,

551 and in excess of oxygen, shows half-order dependence with respect to NO inlet

552 concentration. These results suggest that the dissociative adsorption of NO must be

553 probably involved in the reaction mechanism, under these experimental conditions

554 (temperatures lower than the one needed to reach the maximum NO conversion).

555 On the other hand, the propylene oxidation reaction shows a negative half-order term

556 with respect to NO, at these experimental conditions. These results also support the

557 partial inhibition of the propylene oxidation due to the possible presence of strongly

558 (and apparently dissociatively) adsorbed NO.

559 The influence of NO to propylene molar ratios has been also analyzed. High and

560 selectively $\mathrm{NO}$ reduction to $\mathrm{N}_{2}$ was observed, at $\mathrm{NO}$ to $\mathrm{C}_{3} \mathrm{H}_{6}$ molar ratios higher than

561 one. Furthermore, the role of $\mathrm{N}_{2} \mathrm{O}$ on the NO reduction has been also evaluated. The

562 results indicate that the formation of $\mathrm{N}_{2}$ does not take place via $\mathrm{N}_{2} \mathrm{O}$ intermediate. With

563 regard to the role of oxygen, it seems that the addition of NO at low temperatures

564 produces the displacement of oxygen from the Pt active sites.

565 Based on all the experimental results, the proposed reaction mechanism considers that

566 the three reactants $\left(\mathrm{C}_{3} \mathrm{H}_{6}, \mathrm{NO}\right.$, and $\left.\mathrm{O}_{2}\right)$ are adsorbed on the same type of Pt adsorption 
567 sites and their corresponding fractional coverages will strongly depend on the

568 experimental condition used. Besides, it takes into account that both the dissociative

569 adsorption of $\mathrm{NO}$ and activation of the hydrocarbon can take place simultaneously.

570 Furthermore, the participation of oxygen from the gas phase in the NO reduction has

571 been also taken into account in this reaction mechanism. Lastly, the direct oxidation of

572 propylene in the presence of oxygen and by its reaction with NO has also been

573 considered.

574 The parameters obtained by the resolution of the model equations indicate that the redox

575 mechanism (dissociative adsorption of NO) presents a major relevance than the

576 mechanism of hydrocarbon activation followed by its reaction with NO. These results

577 are in concordance with the high selectivity to $\mathrm{N}_{2}$, because the majority presence of

578 dissociated $\mathrm{NO}$ avoids the formation of $\mathrm{N}_{2} \mathrm{O}$ by the reaction of molecular $\mathrm{NO}$ with $\mathrm{N}$

579 dissociated from $\mathrm{NO}$. Both $\mathrm{NO}$ reduction and $\mathrm{C}_{3} \mathrm{H}_{6}$ oxidation conversions are

580 represented reasonably well by the model proposed.

581 NOMENCLATURE

582 D reactor diameter $[\mathrm{m}]$

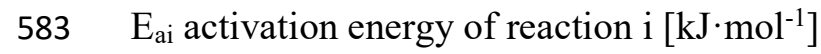

$584 \Delta$ Hi enthalpy of reaction i $\left[\mathrm{kJ} \cdot \mathrm{mol}^{-1}\right]$

$585 \quad k_{i}$ kinetic constant of reaction $\mathrm{i}\left[\mathrm{mol} \mathrm{g}^{-1} \mathrm{~s}^{-1}\right]$

$586 \mathrm{k}_{\mathrm{oi}}$ preexponential factor of reaction $\mathrm{i}\left[\mathrm{mol} \mathrm{g}^{-1} \mathrm{~s}^{-1}\right]$

$587 \quad \mathrm{~K}_{\mathrm{i}}$ equilibrium constants of reaction $\mathrm{i}\left[\mathrm{M}^{-1}\right]$

$588 \mathrm{~K}_{\mathrm{oi}}$ preexponential factor of reaction $\mathrm{i}\left[\mathrm{M}^{-1}\right]$ 
589

590

591

$592 \quad X_{i}$ conversion of reactive $\mathrm{i}$

$593 \mathrm{~W} / \mathrm{F}_{\mathrm{NO}}$ nitric oxide space time $\left[\mathrm{g} \mathrm{s} \cdot \mathrm{mol}^{-1}\right]$

594 Greek letters

$595 \theta^{*}$ fraction of free platinum sites

$596 \quad \theta * i$ fractional coverage of $i$ specie on platinum sites

597 ACKNOWLEDGEMENTS

598 This work was supported by the Spanish Ministry of Economy and Competitiveness

599 under CTQ2012-36408 and CTQ2015-68654-R projects.

\section{REFERENCES}

601 [1] Z. Zhang, M. Chen, Z. Jiang, W. Shangguan, J.Hazard. Mater. 193 (2011) 330.

602 [2] J. Li, J. Hao, L. Fu, T. Zhu, Z. Liu, X. Cui, Appl.Catal. A: Gen. 265 (2004) 43.

603 [3] X. Liu, Z. Jiang, M. Chen, J. Shi, Z. Zhang, W. Shangguan, Ind. Eng. Chem. Res. $604 \quad 2011,50,7866$.

605 [4] A. Obuchi, A. Ohl, M. Nakamura, A. Ogata, K. Mizuno, Hl. Ohuchi, Appl. Catal. B 606 Environ. 2 (1993) 71.

607 [5] R. Burch, P.J. Millington, Catal. Today 26 (1995) 185.

608 [6] H. Hamada, Catal. Today 22 (1994) 21.

609 [7] http://epa.gov/climatechange/ghgemissions/gases/n2o.htm 
610 [8] R. Burch, P.J. Millington, A.P. Walker, Appl. Catal. B-Environ. 4 (1994) 65.

611 [9] R. Burch, J.A. Sullivan, J. Catal. 182 (1999) 489.

612 [10] G.P. Ansell, A.F. Diwell, S.E. Golunski, J.W. Hayes, R.R. Rajaram, T.J. Truex,

613 A.P. Walker, Appl. Catal. B-Environ. 2 (1993) 81.

614 [11] D.K. Captain, Michael D. Amiridis, Catal. Today 42 (1998) 93.

615 [12] V. Pitchon, A. Fritz, J. Catal. 186 (1999) 64.

616 [13] F. Garin, P. Girard, S. Ringler, G. Maire, N. Davias, Appl. Catal. B-Environ. 20

617 (1999) 205.

618 [14] O. Gorce, F. Baudin, C. Thomas, P. Da Costa, G. Djéga-Mariadassou, Appl. Catal.

619 B-Environ. 54 (2004) 69.

620 [15] R. Ruiz-Rosas, J.M. Rosas, I.G. Loscertales, J. Rodríguez-Mirasol, T. Cordero,

621 Appl. Catal. B: Environ. 156-157 (2014) 15.

622 [16] I.G. Loscertales, A. Barrero, I. Guerrero, R. Cortijo, M. Márquez, A.M. Gañán-

623 Calvo, Science 295 (2002) 1695.

624 [17] R. Burch, J.A. Sullivan, T.C. Watling, Catal. Today 42 (1998) 13.

625 [18] I.V. Yentekakis, V. Tellou, G. Botzolaki, I.A. Rapakousios, Appl. Catal. B

626 Environ. $56(2005) 229$.

627 [19] J.M. García Cortés, M.J. Illán Gómez, C. Salinas Martínez de Lecea, ,Appl. Catal.

628 B: Environ. 74 (2007) 313.

629 [20] A. Kotsifa, D. I. Kondarides, X.E. Verykios, Appl. Catal. B: Environ. 80 (2008)

630260.

631 [21] S.-C. Shen, S. Kawi, J. Catal. 213 (2003) 241.

632 [22] P. Denton, A. Giroir-Fendler, Y. Schuurman, H. Praliaud, C. Mirodatos, M. Primet,

633 J. Catal $189(2000) 410$. 
634 [23] A.A. Nikolopoulos, E.S. Stergioula, E.A. Efthimiadis, I.A. Vasalos, Catal. Today $63554(1999) 439$.

636 [24] J. Yang, H. Jung, Chem. Eng. J. 146 (2009) 11.

637 [25] M. Konsolakis, C. Drosou, I.V. Yentekakis, Appl. Catal. B: Environ. 123- 124

$638 \quad(2012) 405$.

639 [26] M. Khosravi, C. Sola, A. Abedi, R.E. Hayes, W.S. Epling, M. Votsmeier, Appl.

640 Catal.B: Environ. 147 (2014) 264.

641 [27] J. Li, G. Luo, Y. Chu, F. Wei, Chem. Eng. J. 184 (2012) 168.

642 [28] M. Crocoll, S. Kureti, W. Weisweiler, J. Catal. 229 (2005) 480.

643 [29] B. Shen, X. Lin, Y. Zhao, Chem. Eng. J. 222 (2013) 9.

644 [30] C. Sampara, E. Bissett, M. Chmielewski, D. Assanis, Ind. Eng. Chem. Res. 46

$645 \quad(2007) 7993$.

646 [31] D. Bhatia, R.W. McCabe, M.P. Harold, V. Balakotaiah, J. Catal.s 266 (2009) 106.

647 [32] S.S. Mulla, N. Chen, L. Cumaranatunge, G.E. Blau, D.Y. Zemlyanov, W.N.

648 Delgass, W.S. Epling, F.H. Ribeiro, J. Catal. 241 (2006) 389.

649 [33] Y. Zheng, M. Li, D. Wang, M.P. Harold, D. Luss, Catal. Today 267 (2016) 192.

650 


\section{Table captions}

Table 1. Kinetic and thermodynamic parameters estimated with the proposed model. 
Figure captions

Figure 1. a) SEM image, bar length $(1 \mu \mathrm{m})$; b) TEM micrograph of the catalyst, bar length $(100 \mathrm{~nm})$; c) HAADF-STEM of the catalyst surface (Pt:red particles), bar length (50 nm); d) HAADF-STEM of submicrotubes (Pt:pink particles; Si: green particles), bar length $(50 \mathrm{~nm})$.

Figure 2. Evolution of outlet gas concentration as a function of reaction time, with 200 ppmv $\mathrm{NO}, 3 \% \mathrm{v} \mathrm{O}_{2}$ and $1500 \mathrm{ppm}_{\mathrm{v}} \mathrm{C}_{3} \mathrm{H}_{6}$, at $210^{\circ} \mathrm{C}, \mathrm{W} / \mathrm{F}_{\mathrm{NO}}=2.88 \mathrm{~g} \cdot \mathrm{s} / \mu \mathrm{mol}$.

Figure 3. NO conversion and $\mathrm{N}_{2}$ selectivity as a function of time on stream with 200ppmv NO, 1500ppmv $\mathrm{C}_{3} \mathrm{H}_{6}$ and $3 \% \mathrm{O}_{2}$, at $200{ }^{\circ} \mathrm{C}, \mathrm{W} / \mathrm{F}_{\mathrm{NO}}=2.88 \mathrm{~g} \cdot \mathrm{s} / \mu \mathrm{mol}$.

Figure 4. a-b) $\mathrm{NO}$ and $\mathrm{C}_{3} \mathrm{H}_{6}$ conversion as a function of $\mathrm{NO}$ inlet concentration, respectively, with 1500 ppmv $\mathrm{C}_{3} \mathrm{H}_{6}$ and $3 \% \mathrm{O}_{2}$, at different reaction temperatures, and at fixed $\mathrm{W} / \mathrm{F}_{\mathrm{NO}}=1.92 \mathrm{~g} \bullet \mathrm{s} / \mu \mathrm{mol}$ (symbols: experimental data; solid lines: predicted data); c) Natural logarithm of the NO reaction rate as a function of the logarithm of the NO inlet concentration.

Figure 5. a) $\mathrm{NO}$ conversions as a function of the reaction temperature at different $\mathrm{C}_{3} \mathrm{H}_{6}$ concentrations, with 200 ppmv $\mathrm{NO}$ and $3 \% \mathrm{O}_{2}$, and at fixed $\mathrm{W} / \mathrm{F}_{\mathrm{NO}}=2.88 \mathrm{~g} \cdot \mathrm{s} / \mu \mathrm{mol} . \mathrm{b}$ ) Natural logarithm of the NO reaction rate as a function of the logarithm of the $\mathrm{C}_{3} \mathrm{H}_{6}$ inlet concentration.

Figure 6. a) Propylene conversions as a function of the reaction temperature at different inlet concentrations, with 200 ppmv $\mathrm{NO}$ and $3 \% \mathrm{O}_{2}$, and at fixed $\mathrm{W} / \mathrm{F}_{\mathrm{NO}}=2.88$ $\mathrm{g} \cdot \mathrm{s} / \mu \mathrm{mol}$. b) Natural logarithm of the $\mathrm{C}_{3} \mathrm{H}_{6}$ reaction rate as a function of the logarithm of the NO inlet concentration, at fixed $\mathrm{W} / \mathrm{F}_{\mathrm{C} 3 \mathrm{H} 6}=0.38 \mathrm{~g} \bullet \mathrm{s} / \mu \mathrm{mol}$. 
Figure 7. NO conversion as a function of the reaction temperature in the presence and absence of 200 ppmv $\mathrm{N}_{2} \mathrm{O}$, with 200 ppmv NO, 1500 ppmv $\mathrm{C}_{3} \mathrm{H}_{6}$ and $3 \% \mathrm{O}_{2}$.

Figure 8 . Evolution of outlet gas concentration as a function of reaction time, with $3 \% \mathrm{v}$ $\mathrm{O}_{2}, 200 \mathrm{ppm} \mathrm{V} \mathrm{NO}$ and $1500 \mathrm{ppm}_{\mathrm{v}} \mathrm{C}_{3} \mathrm{H}_{6}$, at $210^{\circ} \mathrm{C}, \mathrm{W} / \mathrm{F}_{\mathrm{NO}}=2.88 \mathrm{~g} \cdot \mathrm{s} / \mu \mathrm{mol}$.

Figure 9. Evolution of outlet gas concentration as a function of reaction time, with 200 ppmv $\mathrm{NO}$, at $210^{\circ} \mathrm{C}$, after reacting with $\mathrm{NO}-\mathrm{O}_{2}-\mathrm{C}_{3} \mathrm{H}_{6}$ at $260{ }^{\circ} \mathrm{C}$.

Figure 10. a) NO conversions as a function of the space time at different reaction temperatures, with 1500 ppmv $\mathrm{C}_{3} \mathrm{H}_{6}$ and $3 \% \mathrm{O}_{2}$, and at fixed NO concentration, 400 ppmv (symbols: experimental data; solid lines: predicted data); b) $\mathrm{C}_{3} \mathrm{H}_{6}$ conversions as a function of the space time at different reaction temperatures, with $3 \% \mathrm{O}_{2}$, and at fixed NO concentration, 400 ppmv (symbols: experimental data; solid lines: predicted data). 